\title{
LOOKS CAN BE DECEIVING-A COMPARISON OF INITIAL PUBLIC OFFERING PROCEDURES UNDER JAPANESE AND U.S. SECURITIES LAWS
}

\author{
Alan L. Beller, ${ }^{*}$ Tsunemasa Terai, ** Richard M. Levine***
}

\section{INTRODUCTION}

The Japanese Securities and Exchange Law of 1948' ("SEL") is the principal statute governing the primary offering and secondary trading of securities in Japan. Enacted by the Japanese Diet during the Allied Occupation of Japan, the SEL was closely patterned after the U.S. Securities Act of 19332 ("Securities Act") and the U.S. Securities Exchange Act of 1934 ("Exchange Act"). ${ }^{3}$ With regard to public offerings, including initial public offerings ("IPO"), the SEL is substantially similar to the Securities Act, and follows its two principal modes of regulation: (1) the requirement that a registration statement be filed ${ }^{4}$ with and declared effective by the designated

Copyright $\odot 1992$ Law and Contemporary Problems

* Partner, Cleary, Gottlieb, Steen \& Hamilton; licensed gaikokuho jimubengoshi (foreign law advisor) resident in Tokyo.

** Partner, Cleary, Gottlieb, Steen \& Hamilton; licensed gaikokuho jimubengoshi resident in Tokyo.

*** Associate, Cleary, Gottlieb, Steen \& Hamilton; resident in Tokyo.

None of the authors is currently licensed to practice Japanese law. From 1976 until 1991 when he became licensed as a gaikokuho jimubengoshi, Mr. Terai was a licensed bengoshi and member of the Daiichi Tokyo Bar Association.

1. Shoken Torihiki Ho (Securities and Exchange Law), Law No 25 of 1948, as amended ("SEL"); SEL, as amended 1985, is translated in Japan Sec Res Inst, Japanese Securities Laws and Relating Orders 3 (1987).

2. Securities Act of 1933, 48 Stat 74 (1933) ("Securities Act"), codified as amended at 15 USC $\S \S 77 \mathrm{a}-77 \mathrm{z}(1988)$.

3. Securities Exchange Act of 1934, 48 Stat 881 (1934) ("Exchange Act"), codified as amended at 15 USC $\S \S 78 \mathrm{a}-78 \mathrm{ddl}$, 78ee-78hh, 78kk-781l (1988).

4. With certain exceptions set forth in article 2 of Kigyo Naiyo to no Kaiji ni Kansuru Shorei (Ministerial Ordinance concerning Disclosure of Corporate Information, Etc.) (1973, MOF Ordinance No 5) ("MOF Disclosure Ordinance"), small public offerings in which the aggregate issue or sale price is less than $¥ 500$ million (approximately $\$ 4$ million U.S.) are exempt from the registration requirement of the SEL. The issuer of such an exempt offering is required to file only a securities notification with the Japanese Ministry of Finance ("MOF"). SEL art 4(4); MOF Disclosure Ordinance art 4. An analogous "small offering" exemption is provided under Regulation A of the Securities Act, which exempts offerings of $\$ 1.5$ million or less, subject to certain conditions and filing requirements. 
regulatory body; ${ }^{5}$ and (2) the imposition of liability on an issuer and its advisors for any losses suffered by investors due to material omissions or misstatements in either the registration statement or the prospectus. ${ }^{6}$

The SEL provides the same three-phase scheme for a public offering as that set forth in section 5 of the Securities Act. ${ }^{7}$ First, the potential offeror must file a registration statement ("Japanese registration statement") with the Ministry of Finance ("MOF"). 8 Second, there is a "waiting period" between filing and effectiveness, when the lead underwriter, usually the exchange member advising the issuer ("sponsoring securities firm"), and the remainder of the underwriting syndicate may solicit offers to purchase or make offers to sell the new shares of stock covered by the Japanese registration statement; but actual sales may not occur. The syndicate members, in soliciting offers, may use a preliminary prospectus ${ }^{9}$ that omits or summarizes certain information required in the final prospectus. ${ }^{10}$ The third phase begins after the Japanese registration statement becomes effective, ${ }^{11}$ and the syndicate members actually may begin selling the new securities.

Generally, the Japanese registration statement will become effective fifteen days after its submission to the MOF. ${ }^{12}$ However, any amendment ${ }^{13}$ to the

5. Registration is required for solicitations made to "an unidentified and large number of persons" on uniform terms and conditions with respect to either (1) a subscription of securities to be issued by the issuer ("primary offering") or (2) issued and outstanding securities from holders of such securities ("secondary offering"). SEL arts 2(3), (4). According to paragraph 2-1 of Kigyo Naiyo to no Kaiji ni Kansuru Tonatsukai Tsutatsu ni tsuite (the MOF Release Concerning Disclosure of Corporate Information, etc.) (1971, MOF Securities Bureau No 2272) ("MOF Disclosure Release"), solicitations for the subscription of securities made to "approximately fifty or more persons" will be considered to be a "public offering" subject to the registration requirement.

6. See text accompanying notes 26-31. In addition to governing the registration of the primary issuance of securities, the SEL covers secondary market trading, such as an issuer's periodic reporting obligations, the regulation of securities firms, the prohibition on banks and other financial institutions from engaging in securities underwriting, and related matters. Secondary market trading, broker-dealer regulation, and periodic reporting are primarily regulated in the United States under the Exchange Act. An exhaustive comparison of the SEL with the Securities Act and Exchange Act is beyond the scope of this article; however, the authors' impression is that such a study would likely reach analogous conclusions with respect to the predominant differences in regulatory philosophy that distinguish the application of the two bodies of law.

7. See text accompanying notes 21-23.

8. As originally enacted, the SEL was administered by the Japanese Securities and Exchange Commission, which was subsequently abolished. The Securities Bureau of the MOF absorbed its mandate in 1952. See Kazuko Kobayashi, Sengo Kaikakuki ni Okeru Shoken Torihiki linkai (The Securities and Exchange Commission during the Post-War Reform Era), 1258 Shoji Homu 51 (1991).

9. SEL art 13(3); MOF Disclosure Ordinance art 13. A prospectus that contains any omissions or summaries must state that such omissions and summaries have been made in accordance with the SEL and that, in the event of a sale, the final prospectus will be delivered prior to or concurrently with the sale. A preliminary prospectus must also state (1) the date the registration statement was filed; (2) that it has not yet become effective; and (3) that the information contained in the registration statement is subject to correction. MOF Disclosure Ordinance art 14.

10. Any omission or summary in the preliminary prospectus must be made so as not to mislead a prospective investor. MOF Disclosure Ordinance art 13(3).

11. SEL art 15(1).

12. Id at art $8(1)$.

13. The registrant must file an amendment in the event of any material change in the information that must be disclosed pursuant to the SEL. SEL art 7; MOF Disclosure Ordinance art 11 . 
registration statement requires that the fifteen-day waiting period begin anew, ${ }^{14}$ unless the MOF accelerates its effectiveness. ${ }^{15}$ After the registration statement is effective, a final prospectus that includes information contained therein ${ }^{16}$ must be delivered to the purchaser prior to, or at the time of, sale. ${ }^{17}$ A person selling securities in violation of the foregoing provisions ${ }^{18}$ is strictly liable for damages incurred by a purchaser of these securities. ${ }^{19}$

Many of the SEL's provisions closely parallel the registration requirements of the Securities Act, which provides that: (1) in the absence of an exemption from the registration requirements of the statute, ${ }^{20}$ any potential securities offeror must file a registration statement ("U.S. registration statement") with the Securities and Exchange Commission ("SEC");'1 (2) no sales of securities may be made prior to the effectiveness of the registration statement; ${ }^{22}$ and (3) a final prospectus that is part of an effective U.S. registration statement must be delivered prior to, or at the time of, delivery of the confirmation of sale of

14. SEL art $8(2)$.

15. Since the MOF considers the disclosure of corporate information more important than that of securities information, it generally makes effective amendments relating to securities information (such as the determination of an offering price) on the second day after the date of filing such amendment. The exception is when such an amendment would have a significant market impact, as in the case of the change of the number of shares. In this case, an amendment will generally be made effective on the fourth day after filing. See Hiroki Yamakawa, Kaisei Disclosure Seido no Kaisetsu (6), Koryoku Hassei Kikan no Tanshuku, Mokuromisho, Yoshiki to no Kaisei (Exposition of the Amended Disclosure System (6)-Shortening of Waiting Period and Amendments of Prospectus, Forms, Etc.), 1164 Shoji Homu 21 (1988).

16. SEL arts 13(2), (4); MOF Disclosure Ordinance arts 12, 14.

17. SEL art 15(2). The prospectus delivery requirement also applies to secondary sales of securities within three months of their initial issuance, except in the case of listed securities. Id at art 15(3). Sales between two licensed securities firms are exempt from the prospectus delivery requirement. Id at art $15(2)$.

18. Id at art 15.

19. Id at art 16 .

20. Sales by persons other than issuers, underwriters, and dealers are exempt from registration. Securities Act $\S 4(1), 15$ USC $\S \S 77 \mathrm{~d}(1-3)$. An "underwriter" is defined as "any person who has purchased from an issuer with a view to, or offers or sells for an issuer in connection with, the distribution of any security, or participates or has a direct or indirect participation in any such undertaking." Securities Act $\S 2(11), 15$ USC $\S 77 \mathrm{~b}(11)$. Further, for purposes of the definition of underwriter, an "issuer" includes an affiliate of an issuer. Id.

Dealer sales of initially registered securities need not be registered, but in the case of securities of issuers that are not subject to the periodic reporting requirements of the Exchange Act at the time the registration statement is filed, a prospectus meeting the requirements of the Exchange Act must be delivered for a period ranging from 25 to 90 days after the registration statement becomes effective. Securities Act $\$ 4(3), 15$ USC $\$ 77 \mathrm{~d}(5)$. The Securities Act defines "dealers" as including securities dealers acting as principals (which are normally considered dealers) or agents (which are normally considered brokers). Securities Act $\S 2(12)$, 15 USC $\S 77 \mathrm{~b}(12)$. However, unsolicited offers and sales by brokers are always exempt from registration. Securities Act $\S 4(4)$, 15 USC $\S 77 \mathrm{~d}(4)$.

The SEL does not contain these exemptions or other provisions regarding underwriter or dealer transactions. As a result, a secondary market transaction involving the solicitation of 50 or more subscribers could be subject to registration requirements under the SEL. See note 5 . Further, secondary market offers and sales by affiliates of the issuer do not trigger registration requirements under the SEL unless this fifty-offeree standard is exceeded.

21. At the time of its enactment, the Federal Trade Commission administered the Securities Act. With the enactment of the Exchange Act, the SEC was created with the specific authority to administer U.S. securities laws, including the Securities and Exchange Acts.

22. Securities Act $\S \S 5(\mathrm{a}),(\mathrm{c}), 15$ USC $\S \S 77 \mathrm{e}(\mathrm{a}),(\mathrm{c})$. 
the securities. ${ }^{23}$ An investor has a cause of action for rescission or damages if these provisions are violated.

Despite the similarities between the two securities laws, some differences do exist. First, the Securities Act, unlike the SEL, prohibits any written offer prior to the effectiveness of the U.S. registration statement, unless such offer is made by means of a prospectus in a U.S. registration statement. Second, the Securities Act prohibits written offers, even after effectiveness, unless made by means of a final prospectus complying with the requirements of the Securities Act, or of written materials preceded or accompanied by such a statutory prospectus. ${ }^{24}$ Although the SEL does not require that offers be accompanied by a statutory prospectus, it does contain a provision that prohibits the use of a prospectus containing information inconsistent with the SEL's requirements. ${ }^{25}$ The liability provisions of the SEL and the Securities Act are also similar. Both statutes provide a summary of information required to be included in the respective registration statements, and authorize the MOF, in the case of the SEL, and the SEC, in the case of the Securities Act, to provide for detailed disclosure requirements. ${ }^{26}$ Under the SEL, the issuer is absolutely liable to purchasers for materially deficient disclosure in the registration statement or prospectus, unless the purchaser knew of such misstatement or omission. ${ }^{27}$ The issuer's officers and the selling shareholder are similarly liable for material misstatements or omissions in the registration statement or prospectus, unless they can prove a "due diligence" defense. ${ }^{28}$ Auditors are liable for any misstatements or omissions in audited financial statements within a registration statement, unless they can prove that they acted without intent or negligence. ${ }^{29}$ Securities firms involved in "principal underwriting contracts" are also liable for material misstatements and omissions in the registration statement, unless they can establish a "due diligence" defense or, as to financial statements, that they did not know of the misstatement or omission. ${ }^{30}$ The liability provisions of the Securities Act provide for similar apportionment of liability and defenses for the offering participants. ${ }^{31}$

23. Id at $\S 5(b), 15$ USC at $\$ \S 77 \mathrm{e}(\mathrm{b})$.

24. Id at $\S \S 5$ (b)(1), 2(10), 15 USC at $\$ \S 77 \mathrm{e}(\mathrm{b})(1), 77 \mathrm{~b}(10)$.

25. SEL art 13. In addition, the use of any brochure, newspaper advertisement, or any other statement containing a description of the issuer that is different from the description contained in the final or preliminary prospectus is prohibited. Id at art 13(5); MOF Disclosure Release paragraphs 2$3,2-4,4-1$.

26. Securities Act $\$ 7,15$ USC at $\S 77 \mathrm{~g}$; SEL art 5 .

27. SEL arts 18-20.

28. Id at art 21.

29. Id.

30. Id at art $21(4)$. A principal underwriting contract is the agreement between the underwriter and the issuer or the holder of securities sold in a secondary offering.

31. Securities Act $\$ \S 11,12(2), 15$ USC $\$ \S 77 \mathrm{k}, 771(2)$. Under the Act, underwriters and officers and directors of an issuer may rely on the statements of experts, such as accountants, without independent investigation, provided that they have no reason to believe that the statements are not true. Id at $\$ 11,15$ USC at $\$ 77 \mathrm{k}$. Under the SEL, the officers' and directors' due diligence defense requirement extends to audited financial statements. SEL art 21. 
While a comparison between the mechanics of the two statutes demonstrates their facial similarity, such a comparison does not reach the fundamentally different regulatory approaches that mark the administration and actual application of the statutes. ${ }^{32}$ The approach and specific provisions of the Securities Act make clear that, in adopting it, Congress' central policy concern was the adequacy of disclosure.$^{33}$ In that regard, the adoption of the Securities Act was the culmination of a decades-long process focusing on the passage of federal securities legislation mandating adequate disclosure. Market practice and regulatory focus since the adoption of the Securities Act have reinforced the basic thrust of the statute. Offerings required to be registered under the Securities Act are preceded by the determination of what must be disclosed in a U.S. registration statement and prospectus, the drafting of such disclosure, and its verification for purposes of assuring its accuracy and completeness, as well as the establishment of a due diligence defense. This process can be time-consuming and expensive for an issuer that either does not have an established body of disclosure, or that has complex issues that may require disclosure. ${ }^{34}$

The SEL also appears, on its face, to establish a system of securities regulation founded on disclosure. As a matter of market practice and regulatory focus, however, the disclosure-based registration process mandated by the SEL has been subordinated to a substantive review of the proposed issuer to determine whether the issuer is of sufficient quality to merit the issuance of its securities to the public. ${ }^{35}$ While the regulators appear to be placing increased emphasis on disclosure, ${ }^{36}$ the philosophy behind merit review still dominates the approach of both the MOF and the other regulatory authorities involved in the registration and listing process. The primary participants in this merit review process are the Japanese securities exchanges on which listings are sought. ${ }^{37}$

32. For a more detailed treatment of the statutory differences between the SEL and the Securities Act, see Yoshiki Shimada, A Comparison of Securities Regulation in Japan and the United States, 29 Colum J Transnatl L 319 (1991).

33. See text accompanying notes $76-85$.

34. The SEC has adopted rules that have streamlined offering procedures for both issuers with at least a three-year history of filing annual and other periodic reports with the SEC, and for certain types of offerings for issuers generally. See, for example, Securities Act Forms S-2, S-3, F-2 and F-3, 17 CFR $\S \S 239.12,239.13,239.32,239.33$ (1992), which permit incorporation by reference of periodic reports listed under the Exchange Act, and Securities Act Rule 415, 17 CFR $\$ 230.415$, permitting "shelf registration," whereby a registration statement can be filed, declared effective, and then used for future offerings, up to the total amount of securities registered thereon, without requiring a declaration of effectiveness or other action by the SEC. A somewhat similar shelf registration procedure has also been adopted by the MOF under the SEL.

35. See text accompanying notes 150-85.

36. Akira Morishita, Kigyo Naiyo Kaiji Seido-Hokisei no Tenkai to Kadai (Corporate Disclosure SystemLegal Development and Issues) Part I (Chuo Keizaisha, 1991); Katsuro Kanzaki, Tomio Nakajima, Hiroshi Endo, Etsuji Takahashi, Fujio Hattori, Zadankai Disclosure Seido no Genjo to Tenbo (Symposium, Present Situations of Disclosure System and its Prospect), 1083 Shoji Homu 2-5 (1986), 1084 Shoji Homu 8-13 (1986), 1086 Shoji Homu 19-28 (1986).

37. The Tokyo Stock Exchange ("TSE"), a non-profit, quasi-governmental organization composed of member securities firms, is the largest and most influential of the Japanese securities exchanges. 
Japanese registration statements and prospectuses prepared for public offering in Japan conform to many of the same disclosure requirements and include much of the same information as their U.S. counterparts. However, since the only entities that may engage in a registered offering are those that have passed the stringent standards of the merit review preceding the listing on an exchange or the qualification for the trading on the over-the-counter ("OTC") market, both the issuer and the market participants place less emphasis on the disclosure documents and the manner in which difficult disclosure questions are treated. Moreover, the threat of shareholder lawsuits due to a failure to disclose material information, one of the driving forces toward complete and accurate disclosure in the U.S. scheme, is virtually nonexistent in the Japanese market. ${ }^{38}$ Although "due diligence" investigations are also a part of the Japanese registration process, they are less rigorous in connection with the registration process, largely because this procedure has already been performed in the course of the merit review.

The disparate regulatory philosophies that animate the Securities Act and the SEL are reflected in the activities of the governmental agencies that administer the two laws, as well as the securities exchanges and other selfregulatory organizations that are involved in the process. In the United States, the SEC functions as an independent agency, acting in accordance with regulations and procedures that are widely disseminated through its rulemaking and policy release procedures. Even where it acts informally, its conclusions are generally made publicly available through the no-action process. $^{39}$ The MOF is entrusted with the supervision of the Japanese capital markets, and exercises broad discretion in administering the SEL. The MOF is generally regarded as a highly professional bureaucracy, and has been reputed to be the most prestigious and powerful of the Japanese government ministries. ${ }^{40}$ The MOF typically implements its policies through informal, unwritten administrative guidelines, which it gives to a particular sector of the market or to a single market participant. While the MOF is not directly involved in the merit review of a prospective issuer, ${ }^{41}$ the MOF does exercise broad supervisory authority over Japanese securities exchanges, such as the TSE, ${ }^{42}$ the Japan Securities Dealers Association ("JSDA"), ${ }^{43}$ and the licensed securities dealers in Japan. ${ }^{44}$ There is little doubt that the MOF is the primary architect of the principles and policies applied by these various entities in their reviews of potential IPO candidates.

38. See text accompanying notes 196-99.

39. With respect to the availability of documents in connection with the review of a registration statement, see note 121 .

40. Marcus W. Brauchli, As Japan's Economy Gains Clout, Ministry of Finance Struggles, Wall St J A1 col 6 (Dec 20, 1989).

41. See Part IIIB.

42. See SEL ch 5 (describing authority over securities exchanges).

43. See id at ch 4 (describing authority over JSDA).

44. See id at ch 3 (describing authority over securities dealers). 
In order to examine the divergent administration of statutes that are by their terms similar, this article describes the IPO procedures that a nonsovereign domestic issuer follows in the United States and in Japan. ${ }^{45}$ To some extent, the application of the two statutes represents a response to the different historical contexts in which they were enacted. This article, therefore, commences with a brief review of the history of the two respective capital markets and, in the case of the United States, the efforts to regulate IPOs prior to the enactment of the Securities Act: ${ }^{46}$ This article then moves to an examination of the operation and administration of the two statutes, with particular reference to the differences in operation and administration under the SEL from those under the Securities Act. ${ }^{47}$

45. The authors have selected the process involved in IPOs because it appears to illustrate most clearly the dominant procedures of the two systems and the "gatekeeper" function of securities regulators (the decision whether securities of an issuer will be allowed into the public markets). It should be noted that due to the continued slump of the Japanese stock market, the Japanese securities offering procedures, including the IPO procedures, are under review by the TSE and the MOF. This has already resulted in the adoption of measures to shorten the merit review by the TSE, to reform the pricing formula of securities sold through an IPO, and to improve public disclosure. In spite of these measures, which are due to take effect in January 1993, the authors do not expect that the basic nature of the IPO procedures in Japan will be altered. See text accompanying notes 187-91.

The authors have also elected not to compare offerings by foreign issuers, although superficially such a comparison could raise more "international" issues, primarily because international offerings do not show the fundamental procedures of the U.S. and Japanese systems. In particular, the SEC's review of a first-time non-U.S. issuer's registration statement resembles that of the IPO of a U.S. issuer, described in Part IIIA. Securities Act Form F-1, 17 CFR $\S 239.31$; Exchange Act Form 20-F, 4 Fed Secur L Rptr (CCH) I 29,701 (May 14, 1991).

However, non-Japanese issuers may undertake a registered public offering in Japan in a manner that is substantially different from that applicable to Japanese issuers. Under rules adopted by the MOF in 1989, a non-Japanese issuer with securities listed on an exchange designated by the JSDA, including most of the world's principal securities exchanges, may undertake an "unlisted registered public offering" in Japan. Dai 28 Kai, Okura Sho Shoken Kyoku Nenpo, Heisei 2 Nenban (The 28th Annual Report of the MOF Securities Bureau, 1992 Edition) 237-39 (Kinyu Zaisei Jijo Kenkyusho, 1991). Such an offering requires the filing of a registration statement with the MOF, but no exchange listing or OTC qualification. As a result, the substantive review that accompanies an offering by a Japanese issuer is absent, but review by the MOF of the disclosure in the registration statement does not appear to be any more extensive than where such substantive review exists. It is thus probably fair to conclude that initial offerings in Japan by non-Japanese issuers with listed securities on a major world exchange are more easily accomplished than such offerings in the United States by non-U.S. issuers.

46. In Japan there was little regulation or attempted regulation of IPOs prior to the SEL.

47. This article, because of its general and comparative nature, does not attempt as detailed an analysis of the application or historical development of the laws and regulations as are available from other sources. In particular, the authors have not attempted to duplicate or improve upon the very extensive materials available elsewhere concerning the history of the U.S. securities laws, or their structure or interpretation. The authors point out, and have indeed themselves referred to, a number of such other authorities regarding the U.S. securities laws. Among the notable works with respect to the history of the U.S. securities market are Joel Seligman, The Transformation of Wall Street (Houghton Mifflin, 1982); John Kenneth Galbraith, The Great Crash (Time, 1962); Michael Parrish, Securities Regulation and the New Deal (Yale U Press, 1970); Arthur Schlesinger, Jr., The Crisis of the Old Order (Houghton Mifflin, 1957). With respect to the structure and administration of the U.S. securities laws, see Louis Loss, Fundamentals of Securities Regulation (Little Brown, 2d ed 1988). For a recent treatment with an emphasis on international matters, see generally Edward F. Greene, Alan $L$. Beller, et al, U.S. Regulation of the International Securities Markets (Prentice-Hall, 1992). For a discussion of some of the practical aspects of the IPO process in the United States, see Carl W. Schneider, Joseph M. Manko \& Robert S. Kant, Going Public, 27 Vill L Rev 1 (1981), updated May 1988, (Bowne \& Co., 1988). 
II

\section{Historical Comparison of Regulation in the United States AND JAPAN}

\section{A. Historical Background to the Enactment of the Securities Act}

The enactment of the Securities Act represented the culmination of over thirty years of legislative attempts to provide federal regulation of the securities markets. ${ }^{48}$ Earlier legislative efforts were predictable responses to a series of stock market panics that dated back to the late nineteenth century. ${ }^{49}$ In the aftermath of the stock market crash of 1929 and the resulting revelations of fraudulent financial practices, ${ }^{50}$ a consensus developed within the government and Congress that existing regulation, primarily in the form of state blue sky laws, was inadequate. ${ }^{51}$ Hence, federal legislation was deemed necessary, and was adopted beginning in 1933.52 However, this legislation also was strongly influenced by those earlier debates regarding the proper nature of regulation for financial markets.

At the start of the twentieth century, virtually no federal or state regulation of the U.S. capital markets or their participants existed. While the bulk of trading was carried out through securities exchanges, ${ }^{53}$ these organizations and other trade groups, such as the Investment Bankers Association, believed it was the duty of the individual market participants to provide accurate information about their securities. ${ }^{54}$ In addition to the general reluctance of

48. "Efforts to regulate corporation securities in the United States flourished initially during the first two decades of the twentieth century." Parrish, Securities Regulation and the New Deal at 5 (cited in note 47 ).

49. Securities market panics occurred in the years 1873, 1893, 1907, and 1921. House Consideration, amendment and passage of HR Rep No 5480, 73rd Cong, Ist Sess, 2910, 2944 (1933) ("HR Rep No 5480").

50. See text accompanying notes $72-75$.

51. "[T] me mandatory corporate disclosure system was adopted because of the widely held belief that securities fraud was prevalent and that state laws often could do little to prevent or punish it." Joel Seligman, The SEC and the Future of Finance 214 (Praeger, 1985)("The Future of Finance").

52. Securities Act, 48 Stat at 74. Congress followed by adopting the Exchange Act, the Public Utility Holding Company Act of 1935, 45 Stat 803 ("the 1935 Act"), the Trust Indenture Act of 1939, the Investment Company Act of 1940, 54 Stat 789 ("the 1940 Act") and the Investment Advisors Act of 1940. While the conventional wisdom is that U.S. securities laws provide for disclosure-based regulation, this is particularly true of the securities offerings regulation under the Securities Act. On the other hand, the broker-dealer and market regulation provisions of the Exchange Act, the 1935 Act, and the 1940 Act provide for substantial substantive regulation.

53. The New York Stock Exchange was the dominant securities exchange at this time:

By 1932, there were at least thirty-three other organized securities exchanges in the country; in addition, thousands of unlisted stock and bond issues were traded in unorganized over-the-counter markets. But the New York Stock Exchange alone accounted for as much as three fourths of all listed securities transactions, and in the period between 1928 and 1933 over [ninety percent] of securities brokerage commissions were received by its members. With few exceptions, the securities of the nation's largest publicly owned firms were listed there.

Seligman, The Transformation of Wall Street at 73 (cited in note 47).

54. For example, E.H. Simmons, President of the New York Stock Exchange ("NYSE"), not only believed that the NYSE had no responsibility for policing the public securities markets, he also felt that the NYSE had no duty even to verify the accuracy of a corporation's NYSE listing application: "The New York Stock Exchange is a private organization, and as such is not a suitable means for the 
federal and state governments to interfere in the market, serious questions existed concerning the constitutionality of a federal statute that would purport to regulate the nation's securities markets. ${ }^{55}$ As a result, the only remedy that an investor could normally pursue in the event of securitiesrelated fraud or misrepresentation, even in the most egregious circumstances, was an action in common law fraud.

In 1902, the United States Congress, in one of its first legislative initiatives in the securities area, commissioned the United States Industrial Commission ("USIC") to investigate market practices and to propose a legislative response to curb abuses. In its review of market practices, the USIC was critical of the lack of disclosure that characterized the sale of securities, and it proposed that the offering prospectus be deemed fraudulent unless it adequately described the issue. ${ }^{56}$

This early call for disclosure was echoed by the leading politicians of the era. In 1901, President Theodore Roosevelt endorsed disclosure as the "only sure remedy which we can invoke" to protect the investing public. ${ }^{57}$ President William Howard Taft invoked the salutary effect of "effective publicity" as the reason in 1910 and 1911 for his call for a federal incorporation statute, ${ }^{58}$ and the Republican Party platform in 1908 included a plank advocating increased corporate disclosure. ${ }^{59}$ These widely held views accounted for the introduction between " 1904 and 1914 of [twenty] separate bills, none of which were adopted, proposing federal incorporation or federal licensing, several of which would require publicity as a deterrent to overcapitalization." 60 While no federal legislation was passed, action was taken at the state level in response to a rash of fraudulent securities deals throughout the country. In 1911, Kansas become the first state to enact a so-

performance of an obviously public function." Parrish, Securities Regulation and the New Deal at 39 (cited in note 47), quoting E.H. Simmons, Security Frauds: A National Business Liability, 14-15 (1927).

55. President Herbert Hoover's professed reluctance to enact any federal securities legislation was based, among other reasons, on his sense of the "doubtful constitutional authority" of such a measure. Seligman, Transformation of Wall Street at 50 (cited in note 47), quoting Ray Lyman Wilbur \& Arthur Mastick Hyde, The Hoover Policies, 347 (C. Scribner's Sons 1937). As with other New Deal legislation, the constitutionality of the Securities Act was also questioned. For example, during the House consideration of the bill that would become the Act, Representative Cox questioned the authority of Congress to enact such a law: "Does not the gentleman see in this measure the projection of the Federal power, under Congress exercising its authority under the commerce clause to the point of uprooting and destroying all police power of States . . ." HR Rep No 5480 at 2920 (cited in note 49 )

56. 82 House Documents, 19 Industrial Commission Reports, Final Report, H Doc No 380, 57th Cong, lst Sess 639-50 (1902).

57. Seligman, The Future of Finance at 215 (cited in note 51), quoting 69-A FTC, Utility Corporations, S Doc No 92, 70th Cong, lst Sess at 106 (1935).

58. Id.

59. Id.

60. Id. This approach to the perceived failings and deceptions in the securities markets was most forcefully articulated by Louis Brandeis prior to his appointment as Associate Justice to the U.S. Supreme Court. In a memorable refrain that would later resonate in the rhetoric of the New Deal, Brandeis remarked about the value of disclosure: "Publicity is justly commended as a remedy for social and industrial diseases. Sunlight is said to be the best of disinfectants; electric light the most efficient policeman." Louis D. Brandeis, Other People's Money 62 (National Home Library Foundation, 1933). 
called "blue sky" securities law, so named because it sought to control those who "would sell building lots in the blue sky in fee simple." 61 By the time of the enactment of the Securities Act, every state (with the exception of Nevada) and the Territory of Hawaii had adopted a blue sky statute. ${ }^{62}$

The focus of many of these statutes differed from the proposed "disclosure" statute advocated by Brandeis. Rather than merely requiring disclosure, many states opted for a preventative approach to the regulation of the public securities market by imposing a qualitative standard in determining whether the proposed offering was safe enough to "merit" being offered to its citizens. ${ }^{63}$ State governments adopting this approach were intent on screening prospective offerings to eliminate all but the most legitimate transactions. According to this view, disclosure alone, though a necessary first step, was not sufficient protection because it did not even purport to prevent fraud. Rather, it provided an aggrieved purchaser with only the remedy of "locking the stable door after the horse has been stolen." 64

Despite their ambitious scope, these state blue sky statutes were easily evaded. ${ }^{65}$ The vast majority of states could ill afford the personnel or other costs that such a qualitative review entailed. ${ }^{66}$ Even if the states had been able to administer the statutes effectively, the blue sky laws as drafted were notoriously porous. Most contained a broad range of exemptions for securities and transactions, including issuances by investment companies, listed companies, insurance companies, and "friendly" foreign issuers. ${ }^{67}$

61. See Loss, Fundamentals of Securities Regulation at 8 (cited in note 47); Thomas Mulvey, Blue Sky Law, 36 Canadian L Times 37 (1916). Another possible derivation of the term "blue sky" statute is a U.S. Supreme Court case that discussed "speculative schemes that have no more basis than so many feet of blue sky." Hall v Geiger-Jones, 242 US 539, 550 (1917).

62. Department of Commerce, $A$ Study of the Economic and Legal Aspects of the Proposed Federal Securities Act, appearing in "Federal Securities Act" Hearings, House Commerce Committee, 73rd Cong, 1st Sess, 94 (1933)(“Commerce Department Study”).

63. In interpreting this standard, which is often formulated as a "fair, just and equitable" standard, the administrative body will consider such factors as "the economic potential of the venture," and its "reasonable investment merits." See Louis Loss \& Edward Cowett, Blue Sky Law 67-81 (Little Brown, 1958).

64. Federal Securities Act, Hearings on HR 4314 before the House Interstate and Foreign Commerce Committee, 73rd Cong, lst Sess 52 (1933)("Hearings on HR 4314")(statement of Congressman Charles A. Wolverton).

65. "Notwithstanding these protective [state blue sky] laws, there has never been a period in history when the public has been so grossly mulcted of accumulated savings by shrewd and conscienceless 'securities' manipulators, as during recent years." Commerce Department Study at 94 (cited in note 62).

66. In addition, few states had personnel with the administrative expertise to perform such reviews.

In forty states, administration [of blue sky laws] usually rested with overburdened, underpaid and often unspecialized agencies, including bank superintendents, railroad commissions, secretary of states, attorney generals, state auditors, insurance commissions, bank examiners or general license directors. Many administrators . . . continued to be short-term political appointees who rotated in and out office without developing a coherent sustained policy.

Parrish, Securities Regulation and the New Deal at 28-29 (cited in note 47).

67. Seligman, The Transformation of Wall Street at 45 (cited in note 47); Commerce Department Study at 100 (cited in note 62). Many statutes exempted companies listed on an exchange, so that 
The greatest infirmity of any blue sky statute, however, derived from the constitutional limits placed on the state's jurisdictional reach. As a 1932 Senate study noted, the states' jurisdictional limitations made "[t]he most effective and widely used method of evading the provision of State blue sky laws ... operation across State lines."68 In his House testimony in 1933, Robert Healy confirmed that the practice of establishing a cross-border sales and promotion operation was so widespread that ninety percent of the securities transactions in the state of Pennsylvania were effected through the mail and, accordingly, were outside the state's jurisdiction. ${ }^{69}$

From World War I until the enactment of the Securities Act, Congress made periodic efforts to pass federal securities legislation. All of these attempts adopted at least some sort of disclosure-based registration system, with Congressman Taylor's proposal in 1919 calling not only for the filing of a detailed disclosure document, but also for a statutory presumption that an investor had relied upon the disclosure in making his purchase. ${ }^{70}$ Taylor's bill was never reported out of committee, ${ }^{71}$ a fate that other proposals in this area shared.

Following the stock market crash in 1929, Congress, particularly the Senate Banking and Currency Committee during the so-called Pecora hearings, ${ }^{72}$ uncovered an array of fraudulent and manipulative market practices in which many of the country's most respected and established financial and industrial firms had engaged..$^{73}$

listing became (and even today continues to be) valued as insulation from blue sky scrutiny. Parrish, Securities Regulation and the New Deal at 30 (cited in note 47).

68. Commerce Department Study at 100 (cited in note 62).

69. Hearings on HR 4314 at 228-30 (cited in note 64) (testimony of Robert E. Healy). The extent to which the blue sky laws were flouted is perhaps best indicated by an Investment Bankers' Association release issued in 1915 counseling its members to ignore the blue sky laws by "clos[ing] all transactions . . . outside the blue sky state." Parrish, Securities Regulation and the New Deal at 29 (cited in note 47), quoting Investment Bankers Association, Proceedings of Annual Convention 118 (1915)

70. Commerce Department Study at 103 (cited in note 62); Parrish, Securities Regulation and the New Deal at 18 (cited in note 47 ).

71. Seligman, The Future of Finance at 217 (cited in note 51).

72. Stock Exchange Practices, Hearings on S Res 84 before the Senate Committee on Banking and Currency, 73rd Cong, 1st Sess 1 (1933), reprinted in J.S. Ellenberger \& Ellen P. Mahar, 5 Legislative History of the Securities Act of 1933 and Securities Exchange Act of 1934 (Fred B. Rothman, 1973) ("Legislative History").

73. The practices uncovered in the Pecora hearings included the establishment of fraudulent trust schemes by Goldman Sachs and Company; below market sales of securities by J.P. Morgan \& Company to a "preferred list" of customers, including J.P. Morgan partners; a bond issuance syndicated by, among others, Brown Bros. \& Co. and Dillon Read \& Co. where, pursuant to a collateral substitution provision under the bond indenture, investment-grade French government bonds were permitted to be exchanged for nearly worthless Yugoslavian government bonds of an equal face amount; and the underwriting of Peruvian government bonds by the National City Bank of New York ("National City"), at a time when National City knew that the government was in arrears on other borrowings, and in the face of a memorandum prepared by one of National City's Vice President's stating that "the condition of [Peruvian] Government finances is positively distressing." Stock Exchange Practices, Letter from the Counsel for the Senate Committee on Banking and Currency under S Res 84, 73rd Cong, lst Sess 126 (1933), reprinted in Ellenberger \& Mahar, Legislative History (cited in note 72 ). 
In his account of the extent of the losses that investors suffered, Walter Miller, Chief of the Foreign Service Division, Bureau of Foreign and Domestic Commerce, reported: "In the [thirteen] years between 1919 and 1932 [f]rom the best information that we could get, we believe that half of the securities sold were either undesirable or worthless."74 Because such a substantial amount of the country's economic base was at stake, and because the market had failed to police itself, a consensus developed that the federal government should intervene and regulate the securities market. ${ }^{75}$ The question then became a matter of how heavy a hand the government need use to maintain the integrity of the market. As one of the drafters of the Securities Act later noted, the Pecora hearings had so broadly indicted the entire financial community that:

[ $t$ ] he American people lost much of its faith in professions that had theretofore been regarded with a respect that had approached awe. As the criticism mounted, doubts as to the value of the very system of private enterprise were generated, and a wide demand was prevalent for the institution of procedures of governmental control that would in essence have created a capital issues bureaucracy to control not only the manner in which securities could be issued, but the very right of any enterprise to tap the capital market. ${ }^{76}$

The principal drafters of the Securities Act, heavily influenced by Brandeis, crafted a measured response to the prevalent deficiencies in the securities markets. ${ }^{77}$ As a matter of personal choice, and consistent with the mandate granted by President Roosevelt, ${ }^{78}$ they agreed that disclosure would form the foundation of their proposed system of regulation. ${ }^{79}$ In doing so, they reversed the presumption of caveat emptor by imposing liability on the seller for any misrepresentation or omission of material fact. ${ }^{80}$ They also

74. Hearings on HR 4314 at 80 (cited in note 64).

75. As Congressman Wolverton stated during the House of Representative's consideration of the proposed federal securities act: "Because of the ineffectiveness of State statutes to give adequate protection, there is a demand for the Federal Government to enact regulatory legislation to supplement and make more effective the State regulation designed to protect the investing public." HR Rep No 5480 at 2931 (cited in note 49).

76. James M. Landis, The Legislative History of the Securities Act of 1933, 28 Geo Wash L Rev 29, 30 (1959) (emphasis added).

77. As Felix Frankfurter, one of the central influences on the drafting of the House bill that would form the basis for the Securities Act later wrote, "I was a moderating voice among the draftsmen of the Securities Act . . . an examination of the proposals before I was asked to enter the situation . . will leave no doubt in your mind of that." Parrish, Securities Regulation and the New Deal at 42 (cited in note 47) (letter from Felix Frankfurter to Henry L. Stimson, Feb 20, 1934, HLSP, Box 324); 73d Cong, 1st Sess, in 77 Cong Rec 2919, 2983 (Feb 20, 1934).

78. Discussing the securities legislation he intended to introduce to Congress, President Roosevelt described the proposed Securities Act as representing a crucial but limited duty of the government "to insist that every issue of new securities to be sold in interstate commerce shall be accompanied by full publicity and information, and that no essentially important element attending the issue shall be concealed from the buying public." Roosevelt's Address, 73d Cong, 1st Sess (March 13, 1933), in 77 Cong Reg 937 (March 29, 1933).

79. "Our draft remained true to the conception voiced by the President . . . namely that its requirements should be limited to full and fair disclosure of the nature of the security being offered and that there should be no authority to pass upon the investment quality of the security." Landis, 28 Geo Wash L Rev at 34 (cited in note 76).

80. As summarized in the House Committee report on the drafter's bill, its overriding objective was to "throw the burden of disproving responsibility for reprehensible acts of omission or 
differentiated among the market participants-the issuer, directors, underwriter, dealer, or other expert-in allocating responsibility. This approach reflected the drafters' attempt to strike a difficult balance. On one hand, they sought to "assure the performance by corporate directors and officers of their fiduciary obligations and to impress upon accountants the necessity for independence and a thorough professional approach," 81 yet on the other they did not want to impose "an unjust and insurmountable burden on those who have the responsibility for the conduct of corporate enterprise." 82

A number of legislators who favored federal legislation along the lines of the state blue sky "merit" statutes felt the Securities Act did not go far enough. They insisted that the government needed to control the market by passing on the quality of the securities. Calling for legislation based on the "first theory of protection of investors," Congressman Mott urged that "worthless and illegitimate and fundamentally unsound securities should not be permitted to be sold at all and that the investing public should be protected against them in the first instance by prohibiting their sale." 83

Many in Congress, however, abhorred the notion of the government assuming the responsibility of reviewing and approving securities issuances. Congressman Wolverton asserted, during the House debate on the bill, that such a role would require "a vast and extensive bureau of investigation, charged with the appraisal of property, estimating the probable usefulness of patent rights, or likelihood of productivity of every kind of enterprise." ${ }^{44} \mathrm{He}$ viewed such a bureaucracy as a having the potential to inflict grave injustices upon individual entrepreneurs and the economy as a whole. In a nation both inclined toward limited government and dependent upon speculative ventures for a large number of its industrial advances, this argument carried substantial weight. Indeed, the primary virtue of disclosure for its proponents was that "by requiring the purchaser to be the judge of his own investment, based upon facts made available to him, the government is thereby relieved of a responsibility that some would not be willing to acknowledge as a proper function of government." 85

In the end, of course, a bill providing for regulation based on disclosure was enacted, and that approach has since become the accepted method for the regulation of public offerings in the United States. A similar disclosure-based statute was exported to Japan, forming the base of the SEL. As described below, despite its lineage, the SEL is administered so as to impose the type of

commission on those who purport to issue statements for the public's reliance." HR Rep No 5480 at 9-10 (cited in note 49).

81. Id at 35 .

82. Id at 48. This decision to impose in certain circumstances a standard requiring the demonstration of due care, rather than one of strict liability, for the accuracy of the registration statement led to " $[t]$ he bitterest struggle between the House and Senate members of the Conference Committee." Id.

83. HR Rep No 5480 at 2947 (cited in note 49 ).

84. Id at $2930-31$.

85. Id. 
merit review on initial public offerings that was rejected in favor of the Securities Act.

\section{B. Regulation of the Japanese Securities Markets Prior to the SEL}

The United States enacted the Securities Act in deliberate response to widely publicized and condemned ills of its capital markets. Japan's adoption of the SEL at the direction of General Douglas MacArthur, the Supreme Commander for the Allied Powers, however, represented an attempt to provide a regulatory structure for a market that had hardly existed, let alone been regulated, in the past.

Before World War II, the Japanese capital markets remained relatively immature. Indeed, the first joint stock company in Japan was not organized until 1871,86 and this period witnessed only a small number of primary equity issuances and IPOs. ${ }^{87} \mathrm{~A}$ number of factors contributed to this dearth of public offerings. First, many companies established in this period, especially those founded by individual promoters and not related to major industrial conglomerates, such as zaibatsu, ${ }^{88}$ were too small to attract banks or other financial institutions as stock underwriters. Second, many of the companies that were founded during the stock boom of World War I and immediately thereafter were in precarious financial and business positions, making the underwriting of their shares a more risky and difficult proposition than most banks or securities firms were prepared to undertake. ${ }^{89}$ Third, the companies that represented attractive, secure investments consisted largely of companies that were a part of one of the zaibatsu, which relied almost entirely on retained earnings and loans from their holding companies or affiliated banks for their financing needs. Even outside banks and other financial institutions were not given an opportunity to underwrite or purchase their shares, and certainly public investors were not permitted to participate. ${ }^{90}$ Fourth, although Japan had moved rapidly towards industrialization since the late nineteenth century, "the financial benefits of this development became concentrated in the hands of a relatively small group of private businessmen ...."91 As a practical

86. The Kansai Railroad Company issued stock in 1871 that paid a fixed dividend rate. Thomas F.M. Adams, Japanese Securities Markels: A Historical Survey 2 (Seihei Okuyama, 1953).

87. Kaichi Shimura, Nihon Shihonshijo Bunseki (An Analysis of the Japanese Capital Market) 183 (Tokyo U Press, 1969) ("Japanese Capital Market").

88. Major industrial conglomerates included zaibatsu-large corporate groups characterized by extensive cross-shareholdings within each group and control of the group held by the family of the founder of the group. Rodney Clark, The Japanese Company 42 (Yale U Press, 1979).

89. Shimura, Japanese Capital Market at 267 (cited in note 87).

90. Id at 263 . However, to meet the huge needs caused by heavy industrialization in the 1930 s, zaibatsu families did sell to the public (at premium prices) portions of their stock holdings in many zaibatsu group companies. Proceeds from the sales were in turn invested in these companies for expansion. See id at 239. For a general discussion of zaibatsu, see Eleanor M. Hadley, Antitrust in Japan (Princeton U Press, 1970).

91. Edwin O. Reischauer, Japan-The Story of a Nation 130 (Knopf, 1981). Describing this disproportionate allocation of the wealth from Japan's industrializing economy, W. G. Beasley noted, "The town profited more than the village, the owner and manager more than the urban worker. It is true that this was in one sense a stimulus to economic development, in that it made possible a high level of savings and investment, for example, and ensured ample supplies of cheap industrial labor, 
matter, therefore, the number of individuals who could even contemplate investing in securities prior to World War II was quite small. The bulk of the population was more concerned with basic needs than with investment opportunities. Indeed, this lack of public investment in the markets has only recently changed. "Until the mid-1970s, the primary market of equities in Japan was extremely restricted, even compared with the secondary market which was tiny."92

Although precise data regarding IPOs alone are difficult to obtain, the attached tables illustrate the general shallowness of the public capital markets prior to World War II. As Table I (see appendix) shows, the percentage of public offerings during the two stock boom periods of World War I and after the Manchurian Incident in 1931 tended to be approximately five percent of the total amount of equity issued by Japanese corporations. In 1920, when the absolute number of publicly issued securities peaked, public offerings still accounted for only 3.5 percent of all shares issued by Japanese corporations. Table II, which provides a comparison of the total amount of capital provided to 402 major Japanese companies incorporated during the two pre-War stock boom periods, shows that public investors were the least important sources of capital. Table III, which shows a comparison of capital finance methods conducted by the 402 Japanese companies included in Table II, also demonstrates the relative insignificance of the public markets as a source of capital formation. During the period 1914 through 1937, except for one twoyear period (1916-17) and the year 1933, the public capital markets accounted for no more than 9.4 percent of the total amount of capital raised by the 402 major companies. Moreover, those three years of relatively high public capital financings were boom years in Japan, during which businesses needed capital for expansion and public demand for securities rose. ${ }^{93}$ Even during those relatively prosperous times, however, financings through rights offerings to existing shareholders dwarfed the amounts raised on the public capital markets. ${ }^{94}$

With such a high percentage of equity securities held by members of zaibatsu groups, banks, and other essentially permanent holders, physical securities available for trading in the secondary market were scarce. As a result, the secondary market also developed fitfully. ${ }^{95}$ A number of stock

but it also threatened to bring political unrest." William G. Beasley, The Modern History of Japan 189 (Praeger, 1963).

92. Takeji Yamashita, Japan's Securities Markets, A Practitioner's Guide 17 (Butterworths, 1989).

93. With Europe's attention and industrial production diverted from its Asian markets during World War I, Japan was able to expand its export markets in Asia. See Beasley, The Modern History of Japan at 214 (cited in note 91); Reischauer, Japan-The Story of a Nation at 157 (cited in note 91).

94. The relative proportion of capital raised through merger and rights offerings varied, depending on the health of the economy. The years in which merger-led financing played a significant, at times dominant, role in the capital financings of Japanese corporation were years of economic downturn (for example, the years following World War I when, to the detriment of Japan, the Europeans returned to reclaim the Asian markets that they had neglected during the War; and 1930 when Japan's economy lagged as the United States entered the first full year of the Depression).

95. See Mitsuru Misawa, Securities Regulation in Japan, 6 Vand J Transnatl L 447 (1973); Adams, Japanese Securities Markets at 6-34 (cited in note 86). 
exchanges were organized in the late nineteenth century, and the government attempted to regulate them. ${ }^{96}$ However, the trading on such exchanges was patterned on the futures trading that had developed in the rice and silk markets in Japan. ${ }^{97}$ In particular, the vast majority of exchange secondary market trading that took place in the late nineteenth and early twentieth century did not involve physical delivery of shares, but rather cash settlements based on movements in the market price. As Table IV indicates, from 1894 to 1912 only approximately ten percent of the trading on the Tokyo Stock Exchange involved delivery of physical shares; even in the peak year in that period, 1907, only eleven percent of such trading involved physical delivery. ${ }^{98}$ The Japanese government made several attempts to restrict futures trading on securities, but were opposed by stock brokers. ${ }^{99}$

Finally, in 1893 the Stock Exchange Law was enacted, which incorporated some aspects of the Anglo-American approach to the organization and trading of securities on a stock exchange, but permitted futures trading and the cash settlement of securities trades. ${ }^{100}$ The Stock Exchange Law remained the principal element of securities regulation in Japan until 1937, when, with the war in Asia already well underway, emergency legislation was enacted to allocate capital in a manner consistent with a war-time economy. It was thereafter necessary to obtain governmental approval before a corporation could undertake stock financing. ${ }^{101}$

Following World War II, in keeping with the terms of the Potsdam Declaration, 102 General MacArthur ordered a number of steps toward democratizing the economy. First, he dissolved the zaibatsu in 1945, distributing the shares in the constituent companies primarily to the companies' employees and the local inhabitants of the areas in which their factories were located, as well as to the general public. ${ }^{103}$ In 1946 , he directed the government to issue a new currency, and to freeze amounts over a certain limit in individuals' bank accounts. ${ }^{104}$ Securities, however, were one of the

96. See Adams, Japanese Securities Markets (cited in note 86).

97. Id at 23-25.

98. These types of transactions also developed in the United States, but were prohibited in most states as a result of "bucket shop" or gaming statutes adopted around the turn of the century. In the case of New York, these types of speculative transactions were prohibited in 1899 with the passage of the New York State Bucket Shops statute. 1899 NY Laws 1558-59.

99. Seiji Yoshida, Torihikisho Ho no Seitei (Enactment of Stock Exchange Law), in Hiromi Arisawa, ed, Shoken Hyakunen Shi (A Hundred-Year History of Securities) 24-27 (Nihon Keizai Shimbunsha, 1978).

100. Id.

101. Akira Hara, "Nikka Jihen to Shoken Shijo" ("Sino-Japan Incident and Securities Market"), in Arisawa, ed, A Hundred-Year History of Securities at 148-51 (cited in note 99).

102. The Potsdam Declaration called for the "removal of all obstacles to the revival and the strengthening of democratic tendencies among the Japanese people." Department of State, 2 Foreign Relations of the United States: Conference of Berlin (Potsdam) 1474, 1476 (July 26, 1945).

103. Thomas F.M. Adams \& Iwao Hoshii, A Financial History of the New Japan 23-24 (Kodansha Intl, 1972) ("A Financial History"). See also Kaichi Shimura, Shokenseido Kaikaku (Reform of Securities System) contained in Tokyo University, Social Science Institute, Sengo Kaikaku-7 Keizai Kaikaku (Post War Reform Vol 7 Economic Reform) (Tokyo University, Social Science Institute, 1973).

104. Adams \& Hoshii, A Financial History at 31-39 (cited in note 103). 
few items that could be purchased with frozen funds. ${ }^{105}$ These purchases occurred over the counter since General MacArthur had closed all of the stock exchanges in 1945. ${ }^{106}$

With a substantial number of retail investors entering the equity market, General MacArthur required that the government adopt the SEL as a condition to reopening the TSE. The purpose behind this requirement was to protect the investing public and transform the securities market from a forum for speculation into a market for capital accumulation. ${ }^{107}$ In addition to introducing a registration procedure based on the Securities Act, the SEL included a periodic disclosure system for publicly held companies modeled after the Exchange Act, effected a division between the banking and securities businesses, ${ }^{108}$ and abolished the trading of securities as cash-settled futures contracts. ${ }^{109}$

In this manner the SEL was modeled after the U.S. securities laws, but was imposed on a financial system that had a completely different history than that of the United States. Indeed, at the time of the SEL's adoption, the Japanese financial system had almost no history of the type of public financial markets that MacArthur attempted to create, and that laws such as the Securities Act and the SEL were designed to regulate.

Even after MacArthur created widespread public ownership of Japanese securities and imposed U.S. methods of regulation onto the Japanese financial system, the public offerings that the SEL was supposed to regulate were slow to come. Throughout the $1950 \mathrm{~s}$ and $1960 \mathrm{~s}$, the Japanese government supervised a system where, as was the case before World War II, scarce capital resources were allocated by the government to further recovery and development, while capital increases occurred by means of rights offerings to existing shareholders. ${ }^{10}$ Only in the 1970s did public offerings of equity become common, 111 with the boom years for such offerings occurring in the 1980s.

Even when a public offering market developed, careful consideration of what offerings should be permitted and how development should be directed

105. Robert Zielinski \& Nigel Holloway, Unequal Equities-Power and Risk in Japan's Stock Market 28 (Kodansha Intl, 1991) ("Unequal Equities").

106. Adams \& Hoshii, A Financial History at 37-38 (cited in note 103).

107. Thomas F.M. Adams \& Iwao Hoshii, A Financial History of Modern Japan at $201-02$ (Research Japan Lid., 1964).

108. SEL art 65. In the words of one group of commentators, "[t]he imposition of article 65 was a product of the interesting American belief that a democratic regime not only required free election, free speech and due process, but also antitrust laws and the Glass-Steagall Act." David G. Litt, et al, Politics, Bureaucracies, and Financial Markets: Bank Entry into Commercial Paper Underwriting in the United States and Japan, 139 U Pa L Rev 369, 380 (1990).

109. As an observer of the early days of the SEL, Adams later wrote, "many prohibitions were unpleasant to some members [of the Exchanges] and definitely unwelcomed by the less reliable." Adams, Japanese Securities Markets at 44 (cited in note 86).

110. Masami Ogayu, Kabushiki Hakko Shijo (Stock Issue Market), in Arisawa, ed, A Hundred-Year History of Securities 294-97 (cited in note 99).

111. Kiichiro Kitaura, Jika Hakko (Stock Issuance at Market Prices), in Arisawa, ed, A Hundred-Year History of Securities at 338-41 (cited in note 99). 
continued. As a result, while the legal framework of the SEL provided that disclosure alone was required to access the capital markets, the Japanese government and financial system added a substantive review of potential issuers that, as described in Part III, became a far more important step for an issuer than disclosure in accessing the capital markets in Japan.

III

\section{Procedures for an Initial Public Offering}

\section{A. In the United States}

A U.S. company preparing for an initial public offering in the United States must accomplish two principal tasks as a legal and regulatory matter. It first must register the securities to be offered under the Securities Act. Registration principally requires the issuer to make full disclosure of all material information regarding its operations and financial condition. In addition, the officers, directors, and advisers of the prospective IPO issuer must engage in a "clean-up" of their company's financial and internal affairs, to permit it to function appropriately as a public company. This process can involve modification or even termination of arrangements among majority shareholders, promoters, or other insiders, or between such persons and the company.

1. Registration under the Securities Act. A first-time issuer under the Securities Act generally files its U.S. registration statement on SEC Form S-1.112 The specified items required to be disclosed on this form are in turn set forth in various SEC rules. ${ }^{113}$ These rules require that the U.S. registration statement contain detailed disclosures. ${ }^{114}$ The U.S. registration statement must contain audited income statements for the last three fiscal years of the company, balance sheets and other financial information as of the end of the last two fiscal years, as well as five years of summary financial information. ${ }^{115}$ A "management's discussion and analysis" section that examines the issuer's

112. 17 CFR $\$ 239.11$. A first-time filer for an offering of $\$ 7.5$ million or less may file a Securities Act Form S-18, which requires slightly less disclosure and imposes slightly less-rigorous accounting rules. 17 CFR $\$ 239.28$.

113. Securities Act Reg S-K sets out the detailed disclosure rules for registration statements and other required SEC filings. 17 CFR $\S 229$. Securities Act Reg S-X sets out detailed rules for preparation of financial statements to be included therein as well as certain standards for qualification of accountants and examination of financial statements. 17 CFR $\$ 210$. The SEC has also promulgated Industry Guides, which set out additional specific disclosure requirements for certain industries such as bank holding companies, or companies engaged in oil and gas operations. Securities Act Reg S-K, 17 CFR §§ 229.800-802.

114. The mandated disclosure requirements relate broadly to an issuer's business, including principal products, research and development, competitive factors and other material matters, properties, management and management compensation, legal and regulatory matters, and transactions with insiders and other related parties. Securities Act Reg S-K, 17 CFR $\$$ 229.101-103 (items 101-03), 229.401-403 (items 401-03), 229.901-915 (items 901-15).

115. Securities Act Reg S-K, 17 CFR \$§.229.301-304 (items 301-04); see generally Securities Act Reg S-X, 17 CFR $\$ 210$. There is no minimum operating history for an SEC registrant; therefore, if an issuer (and its predecessors) have been in business for fewer years than must be reported, financial statements only need be included for such shorter period. 
financial results also must be included. ${ }^{116}$ Where appropriate, the U.S. registration statement must disclose for investors special "risk factors" unique to that issuer. ${ }^{117}$

To ensure adequate disclosure of all material information and establish the basis for a "due diligence" defense in the event that disclosure turns out to be materially deficient, extensive investigations are conducted by the underwriters and both the underwriters' and issuer's advisers (and, where applicable, selling shareholders and others with potential responsibility). These investigations, while generally complete by the time of filing of the registration statement, continue until it becomes effective; new findings can require modifications or additional information.

The U.S. registration statement, including all exhibits, is a public document upon its filing with the SEC. Exhibits include the articles of incorporation and by-laws of the issuer, contracts relating to the offering, such as the underwriting agreement, legal opinions relating to the securities being offered, and all material contracts of the issuer not made in the ordinary course of business. ${ }^{118}$ All successive amendments to the registration statement are also public documents when filed.

The U.S. registration statement is subject to review by the SEC. ${ }^{119}$ In some cases, especially with seasoned issuers, the SEC chooses not to review a U.S. registration statement, instead declaring it effective upon request. ${ }^{120}$ With a first-time filer, however, the SEC almost inevitably will conduct a full review. The review is conducted by staff within the SEC's Division of Corporate Finance. This Division includes its own Office of the Chief Accountant, which will closely examine the issuer's financial statements. When the SEC reviews a U.S. registration statement, it routinely will provide written comments to the parties that identify deficiencies or raise questions as to the disclosure included in the registration statement. The letters containing these comments, and the registrant's replies, are not public documents. ${ }^{121}$

116. Securities Act Reg S-K, 17 CFR § 229.303 (item 303).

117. Id, 17 CFR $\$ 229.503$ (item 503).

118. Id, 17 CFR $\$ 229.601$ (item 601). Because exhibits to the registration statement are public documents, some issuers have particular concern about the requirement to file material contracts because they may include technical specifications, pricing information, or other terms that may be disadvantageous to disclose for competitive or other business reasons. Where public disclosure would raise such issues, confidential treatment can be sought for information required to be filed with the SEC. Securities Act Rule 406, 17 CFR $\$ 230.403$.

119. Securities Act $\$ 8,15$ USC $\$ 77 \mathrm{~h}$.

120. Securities Act Rel No 4934, Fed Secur L Rptr (CCH) I 77,627 (Nov 21, 1968); Securities Act Rel No 5231, Fed Secur L Rptr (CCH) I 78,509 (Feb 3, 1972).

121. While not public documents, SEC comment letters and the responses thereto may be obtained through the U.S. Freedom of Information Act, 5 USC $\$ 552$ (1988) ("FOIA"). Issuers and their counsel seeking to protect against the release under FOIA of their written responses to the SEC's comment letters and other information supplementally provided to the SEC during the registration statement review process may seek confidential treatment of such information. 17 CFR $\S 200.83$. 
In our experience, the Division of Corporate Finance will provide comments (a "deficiency letter") to a prospective issuer within four to six weeks of the filing of a registration statement. Comments are addressed to the issuer or its counsel, and almost invariably address matters involving disclosure in the U.S. registration statement rather than the substance or merits of a particular offering. Following initial comments, a registrant generally files an amendment to the registration statement embodying changes that respond to the SEC's comments, that disclose recent developments since the original filing, or that reflect the results of continuing "due diligence" investigations of the issuer and its affairs by the issuer's officers, the underwriters, or their respective counsel.

An issuer or its counsel also may respond to comments of the SEC's staff by seeking to explain or to convince the staff that the disclosure is appropriate as originally filed. This process can involve written responses to the SEC's comment letter, telephone conversations, or even face-to-face meetings with increasingly senior levels of the SEC staff. It also can involve, usually at the SEC's request, submission of "supplemental information" that is reviewed by the SEC staff, but not made part of the registration statement. Many offerings do not involve the submission of any supplemental information, and, in any event, such submissions are modest in proportion to both the amount and importance of information publicly disclosed in the registration statement. In addition, the SEC can deem the supplemental information to constitute material information that must be included in the registration statement. ${ }^{122}$

When the SEC has determined that disclosure is adequate, it will declare or otherwise allow a registration statement to become effective. ${ }^{123}$ The SEC's objective throughout the registration process is to ensure that the resulting disclosure document provides a materially complete and correct profile of the prospective issuer that enables the investor to make an informed determination of the risks involved in such an investment. While the issuer and its counsel can, and, as described above, often do, seek to persuade the SEC staff that changes in or additions to disclosure are unnecessary, the final determination as to whether disclosure is adequate in these cases rests, as a practical matter, with the SEC, since their cooperation is generally necessary to make a registration statement effective. In addition, because of the detailed SEC rules governing disclosure, ${ }^{124}$ the objective of a materially complete and correct registration statement is often exceeded. This is possibly to the benefit of the securities markets, investors, competitors, and other interested

122. Regarding the public availability of such supplemental information under the FOIA and requests for confidential treatment thereof, see note 118. The SEC can review and comment upon amendments, and almost always does so where it already has reviewed the original registration statement. A registration statement can be amended any number of times prior to becoming effective, and several such amendments are not uncommon, either as a result of ongoing SEC comments, changes in a transaction, or the other causes previously described. Securities Act $\$ 8,15$ USC $77 \mathrm{~h}$.

123. Id.

124. See generally Securities Act Reg S-X, 17 CFR § 210, Securities Reg S-K, 17 CFR § 229. 
parties, but it is at a cost to issuers (not only monetary, but also in competitive and other respects), because these required disclosures often can include items not material to investors and not required in the absence of these rules.

In contrast to the relative rigidity that characterizes the MOF's declaration of effectiveness for a Japanese registration statement and the pricing of an IPO in Japan, ${ }^{125}$ the SEC tends to make allowances for the fluidity of the market. Once the SEC has completed its review of an IPO issuer's registration statement, it permits the filing of a final pre-effective amendment to the registration statement containing the final prospectus to occur either before or after the pricing of the securities. In the former case, the amendment will contain the complete final prospectus, including the IPO price and the underwriters' commission, and the registration statement will be declared effective immediately after the amendment's filing, permitting the commencement of sales. In the latter case, the amendment will contain a prospectus without such pricing information, and the U.S. registration statement will be declared effective on that basis. In this latter case, the offering must be priced within five business days after effectiveness, and sales and sales confirmations can take place immediately on pricing, without further SEC action. ${ }^{126}$

2. Preparing an Issuer for an IPO. Prior to an IPO, prospective issuers and their advisers often are required to go through a series of steps to prepare the issuer for a public offering. Some of the steps are technical or ministerial, such as appointing a bank to be the transfer agent for the issuer's stock; others are primarily forward-looking, such as the establishment of internal accounting and other procedures that will facilitate compliance with accounting, disclosure, reporting, and other requirements applicable to U.S. public companies. ${ }^{127}$ One step in particular-the elimination of non-armslength relationships among the issuer's shareholders, promoters, or other insiders, or between such persons and the issuer-is substantially legal in nature. These kinds of relationships are relatively common in the case of closely held corporations, and can be structured so that they are countenanced under state corporation laws. The adjustment of these

125. See text accompanying notes $187-94$.

126. Securities Act Rule 430A, 17 CFR $\S 230.430$ A. The IPO price and other pricing information must be included in a final prospectus, which is to be filed with the SEC within two business days following the earlier of (1) the date of determination of the IPO price, or (2) the date the final prospectus is first used in connection with the IPO. If, however, the final prospectus is not filed with the SEC within five business days after effectiveness, a post-effective amendment must be filed and declared effective before sales are made, and another five business day period will begin to run from the date of effectiveness of the post-effective amendment. Alternatively, the post-effective amendment could contain the pricing information, and be declared effective in the manner of a traditional pricing amendment. Id; see also Securities Act Rule 424(b), 17 CFR § 230.430A; Securities Act Rule 497(h), 17 CFR \& $230.497(\mathrm{~h})$.

127. Among the requirements to be considered are the periodic reporting requirements applicable to public companies, including the resulting accounting requirements; the proxy requirements; and the record-keeping requirements of the Foreign Corrupt Practices Act. Exchange Act $\S 12,13,14(\mathrm{a}), 14(\mathrm{~b}), 15(\mathrm{~d}), 15$ USC $\S \S 78(\mathrm{l}),(\mathrm{m}),(\mathrm{n}),(\mathrm{a}),(\mathrm{n}),(\mathrm{b}),(\mathrm{o}),(\mathrm{d})$. 
relationships often begins before the commencement of the registration process under the Securities Act. This process can include the termination of certain relationships and modification of others, as well as arms-length asset transfers by insiders to the prospective IPO issuer. If such transfers are not arms-length, they themselves can raise disclosure and substantive legal problems of the sorts described below, and if made in exchange for the issuer's securities, can raise issues regarding "cheap stock," also discussed below. ${ }^{128}$

The need to eliminate non-arms-length relationships is driven by both business and legal considerations. As a legal matter, such arrangements must be disclosed. ${ }^{129}$ Failure to disclose such arrangements where they are material is, of course, also a violation of the disclosure and antifraud provisions of the U.S. securities laws. ${ }^{130}$ From a business perspective, since investors may be disinclined to purchase shares of a company where there are material arrangements favoring insiders, the issuer may have little choice but to terminate the arrangements to have a marketable IPO.

Non-arms-length arrangements raise other legal and regulatory issues for a company that is about to "go public." First, public shareholders are not likely to tolerate the insider arrangements that shareholders of a closely held corporation accept (often to their benefit). If the arrangements favor controlling shareholders, directors, or officers at the expense of minority shareholders or the company itself, they can be challenged under state corporation law, even if they have been disclosed. Such challenges can be brought by the company or, more likely, by minority shareholders acting either on their own behalf, or on behalf of the company through a derivative suit. ${ }^{131}$

Second, in addition to the U.S. federal securities laws, each of the fifty states and the District of Columbia has its own "blue sky" securities laws. In almost every state, offers and sales of securities require either registration under the blue sky law of that state or an exemption from their registration requirement. As described above, since the early 1900s, some states have engaged in a "merit review" of offerings registered in their jurisdictions. 132 Insider relationships can be fatal to the approval of an offering in such a

128. For a brief description of the comparable steps that may have to be taken by a Japanese company, see the text at notes 175-77. For a discussion of the steps that a U.S. issuer should take in contemplation of an IPO, see generally Schneider, Manko \& Kant, 27 Vill L Rev 1 (cited in note 47).

129. Securities Act Reg S-X, 17 CFR $\$ 229.404$ (item 404) requires a description of any related party transaction involving amounts in excess of $\$ 60,000$.

130. Securities Act Reg S-K, 17 CFR \$ 229.303; Exchange Act Rule 10b-5, 17 CFR $\$ 240.10 b-5$.

131. See Brophy v Cities Service Co., 31 Del Chanc 241, 70 A2d 5 (1949); Diamond v Oreamuno, 248 NE2d 910 (NY Ct App 1969). See, for example, Delaware Gen Corp L, 8 Del Code Ann $\S 327$ (1991); FRCP 23.1. See generally George D. Hornstein, The Shareholders' Derivative Suit in the United States, 1967 J Bus L 282 (1967); Bert S. Prunty, The Shareholders' Derivative Suit: Notes on its Derivation, 32 NYU L Rev 980 (1957).

132. See text accompanying notes 60-68. States that currently impose a merit review of a prospective issuer include Arizona (Ariz Rev Stat \$ 44-1921.3); Massachusetts (Mass Gen Laws Ann \$ 305(a) (2)(E) (1984 ed)); Missouri (Mo Rev Stat \$ 409.306(a)(2)(E) (1986)); Ohio (Ohio Rev Code $\S 1707.13)$; and Texas (Tex Rev Civ Stat $\$ 581-10$ (1986)). 
jurisdiction. Even in those states that take an approach more consistent with the Securities Act's disclosure-based registration scheme, certain types of insider transactions still can be an obstacle to registration of an offering. ${ }^{133}$ Under state securities laws, the most troublesome type of transaction for the prospective IPO issuer is the sale to insiders of stock below the public offering price, or for intangible consideration such as services (so-called cheap stock). For a public offering, the most often used exemption from state securities laws is the exemption for offerings of listed securities, and issuers will often avail themselves of listing for precisely that purpose. ${ }^{134}$

Third, insider arrangements with underwriters or their affiliates involving the issuer's securities can be prohibited or restricted as excessive underwriting compensation under the rules of the National Association of Securities Dealers ("NASD"). ${ }^{135}$ Securities of the issuer granted or sold to underwriters or their affiliates below the offering price are considered underwriters' compensation. In addition, the NASD will examine all items of value, including securities, granted to an underwriter or affiliate up to at least one year prior to an offering in determining the amount of compensation received, and will presume that items granted to the underwriters during the six months prior to the offering are compensation. The NASD currently limits total compensation to underwriters in accordance with various objective standards, including a prohibition on an underwriter receiving compensation in the form of securities in excess of ten percent of the number or value of securities offered. ${ }^{136}$

Although the exercise of preparing a company for its IPO addresses, in some cases and in some respects, the substance of a company's operations, this process is not the result of a merit review, and the business issues that are

133. See, for example, RI Gen Laws $\$ 7-11-3-5(\mathrm{~g})$ (1956) under which an insider can be required to place in escrow, for a period of not more than three years, its shares of an issuer if there exists no public market for the issuer's stock, or the issuer did not have significant earnings from operations during the most recent five year period. Tex Admin Code $\$ 113.3(5),(13)$. This section also provides for the escrow of "cheap stock" in certain situations, and that loans made to insiders prior to the registration filing must be ratified by a majority of disinterested directors and fully disclosed in the offering materials. See also Statement of Policy on Promotional Shares, North American Securities Administrators Association, NASAA Rpts (CCH) ףף 3201-3206 (Sept 3, 1987).

134. Currently, all state blue sky laws have an exemption to state registration requirements for securities listed on either the New York Stock Exchange or the American Stock Exchange, except for: (1) states where a filing must be made to perfect the exemption for an exchange listing, for example, Arizona (Ariz Rev Stat \$ 44-1843. A.7); Nevada (Nev Rev Stat \$ 90.520.2(g) (1991)); and New York (NY Rev Stat $\$ 359-\mathrm{f}(1)(\mathrm{k})$ ); (2) states where the listing exemption does not apply to IPOs, for example, Connecticut (Conn Gen Stat \$ 36-490(a)(8) (Rev 1958, Revised to 1989)); New Hampshire (NH Rev Stat Ann § 421-B:17.I(f) (1955)); and (3) Florida, which provides for no exemption from the state registration requirement on the basis of a listing (Fla Stat Ann $\$ 517.07$ (West 1987)).

135. The NASD is a self-regulatory organization of which virtually every U.S. broker-dealer must be a member. The NASD is itself registered with and subject to regulation by the SEC. Exchange Act $\S 15 A, 15$ USC $\S 780-3$. The NASD's Rules of Fair Practice applicable to its members cover a variety of matters relating to customer protection and market integrity. NASD Rules of Fair Practice include the requirement that the terms of certain offerings, including initial public offerings of equity securities, be submitted to the NASD for review and also include limitations on underwriters' compensation. National Association of Securities Dealers, NASD Rules of Fair Practice, Art III $\S 44$, NASD Manual (CCH) १ף 2000D (1992).

136. NASD Rules of Fair Practice, art III, $\S 44$, NASD Manual (CCH) ๆ 2200D (1992). 
confronted differ from or are, at most, one aspect of a merit review. While a merit review addresses the general quality of an issuer, the various restrictions and requirements discussed in this section focus on whether the relationships and transactions between a company and its shareholders, officers and directors, and other "related parties" are on arms-length terms.

3. Listing on the New York Stock Exchange ("NYSE"). Whether a prospective IPO issuer obtains a listing on a U.S. securities exchange or a quotation on NASDAQ will have no bearing on how its registration statement will be treated by the SEC. Nonetheless, it is instructive to compare the listing procedures of the NYSE, the largest and most influential of the securities exchanges in the United States, to those of the TSE. Although the NYSE also must be concerned about the quality of companies that it will list, the review undertaken is not nearly as extensive, its standards not nearly as high, and its exercise of discretion not nearly as broad as that of the TSE. ${ }^{137}$

As in the case of the TSE, the NYSE sets certain minimal objective standards that a domestic listing candidate must meet. For example, the applicant must have: (1) a minimum of 2000 U.S. holders of 100 or more shares (or 2200 U.S. holders and an average monthly trading volume of 100,000 shares during the most recent six months); (2) a consolidated net tangible asset value of at least $\$ 18$ million; (3) a minimum of $1,100,000$ shares publicly held in the United States with a market value of at least $\$ 18$ million, excluding shares held by officers, directors, their immediate family, and shareholders holding ten percent of the shares; and (4) a pre-tax income of $\$ 2.5$ million for its most recent year and $\$ 2$ million for each of the two preceding years (or cumulative pre-tax income of $\$ 6.5$ million for the last three years with a minimum of $\$ 4.5$ million in the last year, and a profit in each of the last three years). ${ }^{138}$ These objective minimum standards should be compared with the minimum standards of the TSE, such as its requirements that an applicant must have shareholders' equity of approximately $\$ 80$ million and pre-tax profits for the most recent year of approximately $\$ 15$ million. ${ }^{139}$

The NYSE Manual does provide that, aside from the minimum requirements, the NYSE may take other factors into consideration in evaluating an applicant. 140 Such other factors include "the character of the market for its products, its relative stability and position in its industry, and whether or not it is engaged in an expanding industry with prospects for maintaining its position."141 Although the NYSE Manual contains no express limit on the NYSE's discretion, in our experience the NYSE has not, at least in recent times, rejected a candidate that met the minimal listing requirements,

137. See text accompanying notes $152-94$.

138. New York Stock Exchange, Listed Company Manual § 102.01, 3 Fed Secur L Rptr (CCH) 23,573 (1990) ("NYSE Manual").

139. See text accompanying note 172.

140. NYSE Manual § 102.01 .

141. Id. 
and we believe that such an action by the NYSE occurs rarely, if at all-a claim that cannot be made about the TSE. Nor does the NYSE have an analogue to the TSE's Pre-Listing Rules that prohibit certain related-party transactions from taking place, irrespective of whether they are arms-length.

The NYSE instead largely looks to its listing agreement with listed companies, rather than to its own review of the past or current activities of a company seeking listing, to provide assurances that the companies will meet its standards. The listing agreement requires the company to provide notices and disclosure of, among other things, changes in the company's business, any change in the supply or terms of listed securities, and any sales of listed securities in excess of fair market value. ${ }^{142}$ The listing agreement also specifies financial accounting and related standards that the listed company must follow, and requires the appointment of an Audit Committee composed of outside directors. ${ }^{143}$

Furthermore, the extent of supporting materials that the NYSE requires is far less than what the TSE requires. For the most part, the supporting materials consist of the applicant's constituent documents, appropriate board of directors' resolutions and certificates, and an opinion of counsel as to standard corporate law issues, and various agreements between the applicant, the NYSE, and the stock transfer agent related to the procedures for trading on the NYSE. ${ }^{144}$ The listing application itself calls for, among other things, "brief," "succinct," "summary" descriptions of the applicant's history, business, management, capitalization, and shareholder relations. ${ }^{145}$ These disclosure requirements regarding the company are almost always more than satisfied by the contents of the registration statement of the company, which is generally appended and referred to in the application. The body of the application itself is generally no more than a handful of pages. As an indication of the more streamlined approach to the listing examination taken by the NYSE, the model timetable in the NYSE Manual aims for the listing of an applicant's stock within five weeks after the submission of the application. ${ }^{146}$

Why is the NYSE not more active in considering the quality of the companies that it lists? Under the Securities Exchange Act of 1934, the NYSE is subject both to SEC regulation and to other U.S. legal standards regarding anticompetitive activity, due process, and other standards of fairness. ${ }^{147}$ These constraints on its exercise of unbridled discretion perhaps explain, in part, its caution in imposing standards beyond its objectively stated requirements, and the provisions of its agreements with issuers. ${ }^{148}$

142. Id at $\$ 901.01$.

143. Id.

144. Id at $\$ 702.04$.

145. Id at $\$ 903.01$.

146. Id at $\$ 702.02$.

147. Exchange Act $\S 6(b)(8), 6(d)(1-3), 15$ USC $\$$ 78(f)(b)(8), (d)(11-3).

148. In fact, the NYSE revises its listing agreement from time to time, often to add additional requirements applicable to listed companies or to tighten standards under which such companies 
Competition for listings with the other U.S. exchanges and the NASDAQ automated interdealer quotation system also explains the NYSE's reluctance to reject listing of issuers that meet its objective standards. ${ }^{149}$ At least as important, however, is the central position of disclosure in the U.S. capital markets, which places the ultimate burden for assessing an issuer on the investor, and the resulting reluctance of the NYSE to substitute its judgment for the market's. Such an approach makes the registration process and the quality of disclosure the main focus of the system. So while the NYSE's listing procedure certainly screens out a portion of the spectrum of applicants, its barriers are not as high as the TSE's, because the basic U.S. regulatory framework is premised on the investor being able to make his or her own investment decision to invest in "blue-chip" companies or, if so inclined, more speculative enterprises.

\section{B. In Japan}

In the United States, the registration of an offering with the SEC in accordance with the Securities Act constitutes the most important legal and regulatory aspect of an IPO. ${ }^{150}$ Under the Securities Act registration process, a prospective issuer can tap the public markets, provided that it properly discloses all material risks of investing in its securities, and this disclosure is satisfactory to the SEC, the underwriters, and the issuer's and underwriters' legal advisers. In contrast, the filing of a Japanese registration statement complying with the SEL, though a requirement for a public offering in Japan, is not the critical step in providing a prospective IPO issuer with access to the Japanese capital markets. Rather, the key step is to obtain either a listing with a Japanese securities exchange or to qualify through the JSDA to have its securities offered on an OTC basis. ${ }^{151}$ To obtain a listing (or OTC status),

operate. However, the NYSE does not generally seek to cause then-listed companies to update their agreement to comply with the new standards until a new listing agreement would be signed for other purposes (for example, a listing of additional securities of that company). Further, it generally does not try to impose the new standards, except on a hortatory basis, to then-listed companies whose agreements do not contain them. See, for example, NYSE Manual $\$ 201.00$. Of course, the NYSE's suggestions and persuasion are often successful in convincing companies to agree to the new provisions, even if they are not in the version of the listing agreement signed by the company.

149. An example of these competitive pressures is seen in the reluctance of the NYSE, the American Stock Exchange, or NASDAQ to cede comparative advantage to the others in the right to list nonvoting or limited voting common stock. Their activities in this regard are discussed in Exchange Act Rel No 24,623, Fed Secur L Rptr (CCH) I 84,143 (June 22, 1987); Exchange Act Rel No 25891, Fed Secur L Rptr (CCH) ๆ 84,247 (July 7, 1988).

150. See Part IIIA.

151. There are eight Japanese securities exchanges, located in Tokyo, Osaka, Nagoya, Kyoto, Sapporo, Hiroshima, Fukuoka, and Niigata, respectively. The TSE is the dominant Japanese exchange, accounting for approximately $85 \%$ of the total stock trading volume on all Japanese securities exchanges, and for more than $95 \%$ of the total market value of listed stock in Japan. Tokyo Stock Exchange, 1991 Fact Book, 91, 93 (1991). Until 1984, only Japanese companies that had obtained a listing on a Japanese exchange were permitted to undertake a public offering. At that time the rules were changed to permit companies that qualified for the OTC market under the rules of the JSDA to undertake an IPO. In 1986 the rules were further liberalized to permit such companies to undertake both an IPO and one subsequent public offering without obtaining a listing, and in 1987 such companies were also permitted to conduct a public offering of convertible bonds. 
and thus to obtain access to the public markets, Japanese corporations must successfully complete a thorough examination of their operational, financial, and managerial soundness. In the case of a listed company, this examination is administered by the officials of an exchange, who will approve for listing only "blue chip" companies. In the case of prospective OTC issuers, ${ }^{152}$ only companies determined to be secure and having substantial prospects for growth are allowed to proceed with registration under the SEL. With the merit review process screening-out unstable or immature companies, the importance of an IPO issuer's public disclosure and the registration process in general is diminished. Accordingly, the discussion below focuses on the review procedures conducted pursuant to the rules of the TSE.

1. TSE Listing Examination. It usually takes three to five years from the time a corporation decides to go public in Japan to the time of the listing and the IPO-far longer than in the United States. ${ }^{153}$ This relatively lengthy lead time generally is required to groom a corporation contemplating a listing to enable it to satisfy the substantive review standards imposed on Japanese issuers. ${ }^{154}$ The TSE's substantive review of a prospective issuer is based on the TSE Listing Examination Criteria for Share Certificates ("TSE Listing Criteria").155 The TSE's decision to grant a listing of the prospective issuer's securities is based on two broad standards: (1) whether such a listing will facilitate fair pricing of, and appropriate trading in, the issuer's securities; and (2) whether such a listing is in the public interest and for the investors' protection. ${ }^{156}$ In so doing, the TSE examines the following matters: (1) the continuity in the management of the prospective issuer's business and the prospects for its future success; (2) its internal administration systems and its record for implementation and compliance with those internal procedures; (3) the quality of its disclosure of corporate information; (4) its relations with affiliated persons; and (5) such other items as the TSE deems necessary. ${ }^{157}$

The central focus of an issuer attempting to comply with these substantive review criteria is the preparation of the Securities Report for Listing Application ("Securities Report"), which will be examined by the TSE. Part I of the Securities Report is identical to the registration statement that is filed

Finally, in 1989 the limitation on subsequent public offerings of shares for OTC issuers was eliminated. Tento Shijo Binran (The OTC Market Handbook) 5, 23, 26, 246 (JSDA, 1991). See also Shoken Dantai Kyogikai (The Conference for Securities Associations), Kabushiki Tento Shijo no Genjo to Kongo no Kadai (Present Condition of the OTC Market for Stock and its Future Problems) 6 (Dec 1991).

152. The merit review process for a Japanese company seeking approval on the OTC market covers matters similar to those covered by the exchanges in the case of obtaining a listing. However, the review process is carried out principally by the two sponsoring securities firms, rather than the JSDA or exchange officials, and is significantly less stringent than that required by the exchanges. Koji Takato, Kabushiki Kokai Jojo no Subete ga Wakaru Hon (The Book that Tells You All About IPOs and Listing) 18 (Chukei Shuppan, 1990) ("IPOs and Listing").

153. Ohta \& Showa Auditing Firm, Kabushiki Kokai Jitsumu Manual Dai San Ban (IPO Practice Manual, 3rd Edition) 14 (Chuo Keizai Sha, 1991).

154. Id.

155. Kabuken Jojo Shinsa Kijun (TSE Listing Criteria) (1949) ("TSE Listing Criteria").

156. TSE Listing Criteria art 2.

157. Id. 
with the MOF under the SEL, and the disclosure requirements are very similar to the SEC's requirements for a U.S. registration statement. ${ }^{158}$ Part II of the Report, however, calls for much more extensive disclosure than Part I, including very detailed and specific information about an issuer's complete business history, all aspects of its current business, its financial information and prospects, and its management. ${ }^{159}$ This information can run into the hundreds or even thousands of pages, and is supplemented by additional information supplied by the issuer in response to the TSE's inquiries.

In effect, Part II goes far beyond the information that is material to an investor, and even beyond the raw information that an issuer would use to prepare disclosure for investors. Part II contains information that is necessary not only for an investment decision, but also for a determination on a comprehensive basis of the quality of the company. Collecting, compiling, or creating this information also requires the company to put in place, if not already present, internal controls and procedures that the TSE believes are appropriate for a public company. ${ }^{160}$ Part II of the Securities Report is not itself publicly available after it is submitted to the TSE, although Part I will, in the form of the Japanese registration statement, become part of the public record. ${ }^{161}$

Given the long-range planning that is required of a listing candidate, a corporation and its sponsoring securities firm will commonly plan for an IPO based on a three- to five-year time frame. It has been suggested that the first phase in planning an IPO, which consists of collecting and compiling all the necessary information, must start as early as possible, and must be completed by the end of the second year prior to the year the Securities Report is filed. ${ }^{162}$ The drafting of the Securities Report generally must begin in the

158. This fact has been strikingly demonstrated to practitioners who have participated in "global" offerings of securities of a non-Japanese issuer that involve a registered public offering in the United States under the Securities Act and a registered unlisted public offering in Japan under the SEL, as well as perhaps offerings in other jurisdictions. In such instances the U.S. registration statement has generally been prepared first, and in practice the Japanese registration statement and prospectus are substantially composed of a Japanese version of various sections of the U.S. registration statement and prospectus, organized into a slightly different order to meet the organizational requirements of the Japanese forms.

159. Pursuant to the TSE Listing Criteria, the TSE must further specifically consider the following: (1) in the case of the company's management and business prospects, the company's history, its officers and principal shareholders, business and operations, labor relations, position in its industry and the prospects for the industry, profit projections and any mergers, acquisitions and dispositions involving the prospective issuer; (2) in the case of the company's administration system, its various internal corporate rules and their implementation, as well as the quality of its budgetary control; (3) in the case of the company's disclosure, the quality of its accounting system, the standards of its accounting treatment and its consistent application thereof, the quality of the disclosure made in its fiscal year-end financial statements, consolidated financial statements and interim financial statements and the quality of other business disclosure that the company provides; and (4) in the case of the company's interaffiliate relations, the parties with an ownership or other business interest in the company and the business dealings that the company has or has had with such parties. Yuka Shoken Jojo Kitei ni kansuru Toriatsukai Yoryo (TSE Release relating to the Handling of the Listing Criteria) \$ 1 (1962) ("Listing Criteria Release").

160. See note 159 regarding the items that must be considered under the TSE's Listing Criteria.

161. See text accompanying note 195.

162. Takato, IPOs and Listing at 116 (cited in note 152). 
year prior to the filing of the Securities Report. ${ }^{163}$ During or prior to the drafting, the prospective issuer may informally contact TSE representatives through the company's sponsoring securities firm to discuss those aspects of the Securities Report or the company's qualifications that raise particular questions. ${ }^{164}$

The final phase of the listing process is the actual submission of the Securities Report to the TSE and the ensuing examination period. Usually the Securities Report will be submitted shortly after the applicant's audited financial statements are available for the fiscal year prior to the year scheduled for listing. After receiving a listing candidate's application materials, the TSE will begin its extensive substantive review. The focus of the TSE, in its review of the Securities Report, is not on the adequacy of the disclosure contained therein, but rather on the quality of the company as described in the Report. ${ }^{165}$

The TSE will take approximately one month to review the documentation and, for the subsequent period of two to three months, will hold fifteen to forty full-day hearings regarding the applicant that will be attended by the applicant's representatives. In the course of the hearings, the TSE will make requests for additional supporting documentation, both for purposes of obtaining such additional information, and as a performance test of the applicant's internal accounting and compliance procedures and controls. The ability of the prospective issuer to respond quickly and accurately to questions raised by the TSE is considered by the TSE in evaluating the quality of the company's management and internal procedures and controls. ${ }^{166}$ In addition to these hearings, the TSE officials also will conduct interviews with the corporation's management and its auditors, and will conduct on-site inspections of the applicant's facilities to confirm the information presented in Part II of the Securities Report. ${ }^{167}$

Two things seem clear about the review process. First, as indicated above, the focus is on the quality of the issuer rather than on disclosure, although it can be assumed that the quality of the disclosure in the Securities Report is generally quite high, since it is the result of a TSE review process that is substantially more detailed than anything that the SEC undertakes. Second, like any review of the substance and merits of a company, even one undertaken by unbiased, high-quality officials, the TSE's analysis of a prospective issuer must be to some extent subjective, and is not itself susceptible to review.

A successful applicant will generally receive informal notice of the TSE's approval of its listing within four to six months after the filing of the Securities Report. The TSE does not publish any official information on the pass rate

163. Id.

164. Id at 139.

165. Id at 208 .

166. Id at 139 .

167. Id at 157-58. 
for listing applicants. One listing advisor estimates from his experience that approximately ninety percent of the applicants successfully conclude the examination, with twenty percent to thirty percent of those who intend to apply for a listing withdrawing from the process prior to submission of a Securities Report to the TSE. ${ }^{168}$ These withdrawals typically occur as the result of a negative response from the TSE, communicated informally through the sponsoring securities firm to the company, often during the course of informal consultations on an aspect of the company's application that casts doubt upon the company's ability to meet the TSE's substantive criteria.

Should the applicant pass the merit examination, it will receive an instruction from the TSE to prepare for the IPO. Shortly thereafter, the TSE will make informal contact with the MOF for approval of the listing, and with the sponsoring securities company for approval of the minimum bid price for the competitive bid process discussed in Part III.B.4.169 These procedures will normally take two weeks. Shortly after the MOF's informal approval, the TSE submits a Listing Application to the MOF170 and makes a public announcement to that effect, including a summary description of the applicant. On the same day or immediately thereafter, the applicant will file its Japanese Registration Statement with the MOF, which will consist of Part I of the Securities Report on file with the TSE. ${ }^{171}$

2. Formal Eligibility Criteria for Listing. Although the most important part of the Japanese listing process, and thus of the IPO process, is the listing examination described above, for a Japanese company to qualify to submit a Securities Report for the TSE's review, a company must as a threshold matter meet the eligibility criteria for listing.

As specified in the TSE Listing Criteria, the following objective standards must be satisfied by a company that is a prospective listing candidate: (1) the total number of the outstanding shares of common stock of the company must be at least $6,000,000$; (2) by the time of listing, the company must have a minimum of 1000 shareholders, with not more than seventy percent of the outstanding shares owned by its ten largest shareholders; (3) the company must have a minimum five-year operating history; (4) the company must have shareholders' equity of at least $¥ 1$ billion (approximately $\$ 8$ million), and per share net assets of at least 100 as of the end of the business year immediately preceding the year of the listing; (5) the company must have earned pre-tax profits for the third fiscal year immediately prior to the listing of $\$ 200$ million, for the second fiscal year immediately prior to the listing of $¥ 300$ million, and for the fiscal year immediately prior to the listing of 400 million; (6) the company must have earned a per share annual profit for the

168. Id at 241.

169. See text accompanying notes $187-94$.

170. SEL art 110. Shoken Torihikisho ni kansuru Shorei (MOF Ordinance concerning Securities Exchanges) art 5 (MOF Ordinance No 76, 1953).

171. Takato, IPOs and Listing at 276 (cited in note 152). 
three most recent fiscal years of at least $¥ 15$; (7) the company must have paid dividends on common stock for the year preceding the listing and have good prospects for continuing to pay per share dividends of at least five years following the IPO; (8) the company must not have made a false entry in its financial statements for the three most recent fiscal years, and there must be no qualification in the auditor's report for the company's most recent fiscal year; (9) the company must appoint a TSE-approved share handling agent; (10) the company must conform its share certificates with the TSE's specified form; and (11) the company cannot restrict the transferability of its shares. ${ }^{172}$ These criteria set sufficiently high barriers so that only companies of substantial size will be able to meet them.

3. Negative Criteria for Listing. In addition to the substantive and formal criteria described above, obtaining a listing on the TSE requires compliance with certain "negative criteria" that can restrict share transfers, reorganizations, and other transactions.

Issuers seeking to go public in Japan will go through a process of preparing for an IPO similar to that undertaken by U.S. companies. ${ }^{173}$ In particular, companies will have to rearrange or terminate relationships with affiliates that will raise problems under the TSE's review process, or are otherwise not appropriate for a public company. These can include relationships with officers, directors, principal shareholders, or companies controlled by such persons or partially owned by the prospective issuer and by one or more of such persons. Such relationships are generally terminated or, where the assets or relationships in question are critical to the prospective issuer's success, are restructured by merging or otherwise transferring the assets in question into the prospective issuer or a wholly owned subsidiary. ${ }^{174}$

The TSE pays special attention to the relationship between a potential IPO issuer and its parent where the issuer is a subsidiary of another company. A number of IPOs in recent years have involved subsidiaries of other companies, including U.S. companies, or, in at least one case, a joint venture company where the joint venture partners have been a Japanese company and a U.S. company. ${ }^{175}$ Parent companies of such a subsidiary seeking to undertake an IPO must themselves be listed on a Japanese or approved foreign exchange. ${ }^{176}$ The parent companies also may not engage in businesses that compete with the prospective IPO company. In addition, there must be an adequate demonstration of independence of the subsidiary

172. TSE Listing Criteria, art 4.

173. See text accompanying notes 127-36.

174. Takato, IPOs and Listing at 200-03 (cited in note 152).

175. IPOs of Japanese subsidiaries of U.S. parents have included those of Levi Strauss Japan in 1989 and Amway Japan in 1991. Kentucky Fried Chicken Japan, a joint venture of Mitsubishi Corporation and Pepsico, undertook an IPO in Japan in 1990. "Kaisha Shikiho" (Japan Company Handbook Spring 1992) (Toyo Keizai, 1992), Japan Company Handbook, Second Section, Summer, 1028, 1032 (Toyo Keizai, 1992) (English edition).

176. Ohta \& Showa, IPO Practice Manual, at 577-78 (3d ed) (cited in note 153). 
from the parent to permit the TSE to conclude that the subsidiary can operate independently following the IPO. ${ }^{177}$

Furthermore, a Japanese company seeking to go public will generally seek before the IPO to place shares with a number of "stable" institutional shareholders that will hold the shares for the long term, support the slate of directors proposed by management, resist any hostile takeover or other overtures, and otherwise support management and its policies. ${ }^{178}$

Finally, founders and other principal shareholders of a company about to go public might, for any number of other legitimate business reasons, seek to rearrange capital structures or shareholdings. Estate tax planning considerations might dictate transfers from an elderly founder to younger family members. The capital structure of the company might have to be changed to accommodate the public offering. Other legitimate reasons might exist to transfer shares.

All of the types of transactions described in the two preceding paragraphs can be restricted by the TSE's negative criteria. First, the TSE Rules for Listing Criteria provide that if the applicant effects any merger, acquisition, or disposition of assets (or acquisition or disposition of a subsidiary) during the year immediately preceding the year in which a listing application is filed, the TSE will reject such applicant's listing application unless any such transaction would have no "material effect" on the applicant. ${ }^{179}$

Second, the TSE Pre-listing Rules ${ }^{180}$ require that it not accept a listing application, or that it revoke acceptance of a previously accepted listing application, if there have been certain interested-party transfers ${ }^{181}$ of the applicant's securities during the period beginning two fiscal years prior to the year in which the listing application was filed, and ending on the date immediately prior to the actual listing ("restricted period"), unless the TSE determines that the purchase or sales price was adequate, and that such acquisition or transfer was made for an appropriate purpose. ${ }^{182}$ For example, a Japanese issuer with a December 31 fiscal year planning to undertake an IPO in 1994 would have a restricted period that commences on January 1, $1992 .{ }^{183}$

177. Id.

178. Ohta \& Showa, IPO Practice Manual, at $79-83$ (3d ed) (cited in note 153). See Zielinski \& Holloway, Unequal Equities at 21-32 (cited in note 105).

179. TSE, Yukashoken Jojo Kitei (Securities Listing Regulation) art 4 (1949). Listing Criteria Release $\$ 7$.

180. TSE, Jojo Zen no Kobo matawa Uridashito no Kisei ni kansuru Kisoku (Regulations on Restrictions on Public Offerings of Newly Issued or Outstanding Shares Prior to Listing) art 15 (1989) ("TSE Pre-listing Rules").

181. These interested party transfers include any acquisition or other transfer of the shares of the applicant by any of the applicant's (or its affiliates') 10 largest shareholders, the securities firms in the proposed IPO syndicate, or certain other interested parties (including the applicant's officers, their spouses, and blood relatives) or companies controlled by any such interested parties. Id.

182. Id; Jozo Zen no Kobo matawa Uridashi no Kisei ni kansuru Kisoku no Toriatsukai (Release Regarding Handling of Regulations on Restrictions on Public Offerings of Newly Issued or Outstanding Shares Prior to Listing) art 14 (1991) ("TSE Pre-Listing Release").

183. The main impetus for the adoption of the Pre-listing Rules came as a direct result of the Recruit scandal of 1988 , in which, shortly prior to an IPO by the subsidiary of a large Japanese 
The Pre-listing Rules place similar restrictions on the ability of an applicant to issue shares during the restricted period. During the first year of the restricted period, the issuer may not issue stock, other than by way of a rights offering to its existing shareholders, unless the TSE determines that the issue price was adequate, and that such issuance was made for an appropriate purpose. ${ }^{184}$ Moreover, the issuer, the sponsoring securities company, and the persons who acquire such new shares must make a written promise to the TSE that: (1) the purchasers will not dispose of such new shares for a period of at least one year after the listing; (2) during such period the sponsoring securities company will take custody of such new share certificates; and (3) the issuer will report to the TSE if any such purchaser disposes of any of such new shares or the sponsoring securities company returns any such new share certificates to one of the purchasers. ${ }^{185}$ Issuances by the applicant other than by way of a rights offering as described above are prohibited throughout the remainder of the restricted period. ${ }^{186}$

\section{TSE Rules Regarding the Pricing of an IPO. In addition to determining} whether a corporation is fit for the public markets, the TSE also prescribes the mechanism for determining the IPO price of the issuer's shares. In an IPO, a certain portion of shares to be offered to the public must be sold in a

company, shares of the prospective IPO issuer were sold to a number of influential political officeholders and other political figures at prices substantially below the expected IPO price, with loans for such purchases provided by affiliates of the issuer. The scandal brought about the resignation of the Japanese Prime Minister and was a major factor in the loss of control of the Upper House of the Japanese legislature by the Liberal Democratic Party ("LDP") - an unprecedented event for Japan and for the LDP, which, except for a brief period in the late 1940s, has controlled both houses of the Japanese Parliament since the first elections following the end of the Allied occupation.

While the Recruit scandal undeniably had serious repercussions for Japan and the LDP, the response, which restricts share transfers and other changes in a prospective issuer's capital structure rather than focusing on possible regulation of payments to public officials by corporations and their officers, seems overbroad. It is as if, in response to a rash of late-night robberies of convenience stores, all convenience stores in Japan were required to close after 6:00 p.m.

It seems clear that restrictions on certain kinds of abusive transactions could be prohibited without interfering with possible legitimate corporate transactions to the same degree as the PreListing Rules in their current form. It also provides an interesting contrast with the U.S. system, where the below-market transfers to officials that resulted in the Recruit scandals would have been clearly actionable, and when discovered would in all likelihood have resulted in actual and massive litigation, both under the antifraud provisions of the U.S. securities laws and state corporation laws.

184. TSE Pre-listing Rules art 17.

185. Id; TSE Pre-listing Release art 15.

186. As a general rule, transactions during the restricted period will be viewed by the TSE as having an appropriate purpose if they are entered into as part of: (1) an intra-family transfer or intragroup transfer; (2) a transfer of shares to an officer or from a retired officer of the applicant; or (3) the applicant's preparation for becoming a public company or establishing of a stable shareholder group. In addition, any such transaction must also be effected at a price equal to $80 \%$ of the minimum offering price for the applicant's shares in the competitive bid process that takes place at the time of the IPO (discussed in note 189), except for intra-family transfers, as to which the TSE does not specify a floor price, and sales to the prospective issuer's employees' stock option association, which must be priced at no less than $70 \%$ of the minimum offering price. Pre-listing Release arts 14-15. 
competitive bid. ${ }^{187}$ The percentage of shares that the applicant intends to issue through the competitive bid process, as well as the calculation of the minimum bid and other information concerning the proposed offering plan, will be submitted to the TSE on the same date that the listing application is filed. ${ }^{188}$ Before conducting the competitive bid, the sponsoring securities firm must calculate the base price that may be bid, based on the amount of per-share net profit and per-share net assets of comparable companies. ${ }^{189}$ The minimum price that may be bid is eighty-five percent of the base offering price, but no maximum limit exists. ${ }^{190}$ The sales price of the remaining shares to be offered to the public will be the weighted-average price of the shares sold in the competitive bid. ${ }^{191}$

Participants in the competitive bidding process can submit bids on the day that the Japanese registration statement is declared effective. ${ }^{192}$ The amount of shares that any one bidder may purchase is restricted. ${ }^{193}$ The calculation of the IPO price (the weighted average of the successful bids in the competitive bid process) occurs on the next successive day, and a post-effective pricing amendment to the Japanese registration statement is then promptly filed with the MOF. Although, as mentioned above, an amendment to the registration statement restarts the fifteen-day waiting period, the MOF generally will

187. Art 4 of the TSE Pre-listing Rules and art 2 of the TSE Pre-listing Release specify a range of shares that must be offered by competitive bid, the amount of which varies depending on the size of the IPO. The applicant and the sponsoring securities firm determine the actual number of shares to be offered within the specified range.

188. TSE Pre-listing Rules art 3; TSE Pre-listing Release art 3.

189. The formula for the base offering price is as follows:

$\mathrm{P}=\mathrm{P}^{1} \times 1 / 2 \times(\mathrm{a} / \mathrm{A}+\mathrm{b} / \mathrm{B})$

where

$\mathbf{P}=$ base offering price in IPO;

$\mathbf{P}^{\mathbf{l}}=$ share price of comparable companies;

a $=$ per share net profit of the company for which listing application is being made;

A = per share net profit of comparable companies;

b = per share net assets of the company for which listing application is being made; and

B = per share net assets of comparable companies.

Comparable companies are selected by the TSE, which consults with the sponsoring securities firm.

TSE Pre-listing Rules art 4. TSE Pre-listing Release art 3.

190. TSE Pre-listing Release art 3(3). Jisyu Kisei Kisoku no Seibi ni Tsuite, (Guideline regarding the Amendment of Voluntary Restrictions) 3 (JSDA and TSE, 1991).

The TSE announced on November 17, 1992 that plans to adopt new rules with respect to, inter alia, the pricing of securities issued through an IPO. These rules, which are expected to be effective in January 1993, would provide the sponsoring securities firm with greater discretion in determining the price of the securities offered to the public. Tokyo Exchange Seeks to Revive Stock Offerings, Asian Wall St. J., November 18, 1992, at B1, col. 3.

191. TSE Pre-listing Release art 8.

192. The registration statement is generally declared effective 15 days after it is filed. See text accompanying note 13. Bids are submitted through securities dealers that are members of the TSE; however, these dealers and their affiliates are not permitted to make bids on their own behalf. TSE Pre-listing Rules art 6.

193. The number of shares that any one entity may purchase is limited to 5000. TSE Pre-listing Rules art 6(4). TSE Pre-listing Release art 3(4). 
accelerate the effectiveness of the Japanese registration statement on the second day after the submission of a pricing amendment. ${ }^{194}$

5. The Registration Process under the SEL. To anyone familiar with the registration of securities pursuant to the Securities Act, the mechanics, form of disclosure and, on their face, procedures involved in the registration of an IPO in accordance with the SEL will appear familiar. Following the approval by the TSE of the Securities Report, the TSE files a listing application with the MOF, and the issuer files its Japanese registration statement, consisting of Part I of the Securities Report, with the MOF. The registration statement becomes a public document upon filing, and contains disclosure regarding the issuer very similar to that required under the Securities Act. ${ }^{195}$ Indeed, since the TSE has undertaken an extensive review of the issuer based on Part II of the Securities Report and other information made available by the issuer, the quality of the disclosure in Part I can be expected to be quite high by the time the Securities Report and listing are approved, even though the focus of the TSE's review is not on disclosure. Generally, what is absent from the Japanese registration statement is a discussion of risk factors, other special considerations regarding the issuer, and other information tailored to an investor's perspective. Potential Japanese investors in an IPO, therefore, have information that may be less nuanced, and somewhat less complete than their U.S. counterparts, but the TSE and the MOF have much more information at their disposal about the issuer than the SEC or the NYSE.

The other principal difference in the registration process with the MOF is that any review by the MOF of the registration statement is a matter of form rather than substance, and comments, if any, by the MOF generally focus on some technical deficiency ${ }^{196}$ rather than on the substance or quality of the disclosure. Coming on the heels of the merit review conducted by a Japanese Securities Exchange or Sponsoring Exchange Member, the MOF's review tends more to be a fine tuning of the registration statement than a rigorous examination of the accuracy and quality of disclosure.

While the MOF has broad authority under the SEL to order an issuer to correct defective disclosure, ${ }^{197}$ to our knowledge this authority is not used by the MOF. Moreover, despite the SEL's framework for apportioning liability for the damages resulting from inaccurate or misleading disclosure, which is roughly analogous to the Securities Act, Japanese investors virtually never resort to legal remedies under the SEL. ${ }^{198}$ In short, the absence of effective

194. See note 15 .

195. See note 113.

196. For example, that information called for by a particular item in the MOF's rules is missing.

197. SEL arts $9(1), 10(1)$ authorize the MOF to order an amendment to a registration statement, and the SEL arts 10(1), 11 authorize the MOF to issue "stop order" suspending an offering.

198. As Professors Jonathan Macey and Hideki Handa observe, “[u]nlike the U.S., Japan has virtually no history of civil litigation over fraudulent transactions of market professionals despite comparable statutory provisions that prohibit fraud on the stock market." Jonathan Macey \& Hideki Kanda, The Stock Exchange as a Firm: The Emergence of Close Substitutes for the New York and Tokyo Stock Exchanges, 75 Cornell L Rev 1007, 1047 (1990). Moreover, there has been little criminal enforcement 
risk of liability for deficient disclosure, the regulator's mechanical approach to disclosure, and the emphasis of the TSE review of the issuer on substantive review rather than disclosure, result, when taken together, in a system where public disclosure and the registration process itself are relatively unimportant elements of an IPO.

\section{IV \\ Conclusion}

To restate what should be obvious by now, Japan was forced, following World War II, to start with a statutory framework for regulating public offerings of securities that followed the model of the Securities Act and focused on disclosure. Japan has left this framework intact, but, as a result of administrative practice and the interpositioning of the stock exchanges or the JSDA in the IPO process, it regulates such offerings through a system where disclosure plays a relatively minor role, and a thorough merit review is the most important step in a potential issuer reaching the public market.

Why did Japan turn to the merit review system? First, there was no particular reason for Japan to take to the disclosure-based system of the Securities Act as embodied in the SEL. The SEL did not derive from prior Japanese experience, as the Securities Act had from earlier U.S. legislative efforts. Further, the disclosure system in the SEL had little relevance to the Japanese economic environment in the 1950s and 1960s. The public securities market that General MacArthur envisioned for the SEL did not materialize. ${ }^{199}$ Similarly, for nearly the first twenty years after World War II, no Japanese public offering market existed to speak of; capital was a scarce resource allocated by the Japanese government among industries it viewed as most important to Japan's recovery and development. ${ }^{200}$ Thereafter, the merit review system that developed allowed the Japanese authorities to direct capital-raising activities in the name of the protection of both industry and investors.

action to date taken by the MOF. See Note, Japanese Securities Regulation: Problems of Enforcement, 60 Fordham L Rev S255 (1992) (authored by Nicole J. Ramsay). Indeed, virtually nothing has altered the system that led Professor Misawa to state in 1973 that "[a]s a practical matter, litigation as a means of enforcing disclosure has proved to be completely ineffective in Japan ...." Misawa, 6 Vand $\mathrm{J}$ Transnatl $\mathrm{L}$ at 447,494 (cited in note 95).

199. While MacArthur distributed shares to employees of the zaibatsu following the end of World War II, the public market that had been envisioned never developed. Instead, many of the employees were in effect wiped out by capital reductions that took place shortly thereafter. Many of the remaining public shareholders sold their shares to holding companies and other institutions during the 1950s and 1960s. Ichiro Kawai, Zaibatsu Kaitai (Dissolving Zaibatsu), in Arisawa, ed, $A$ Hundred-Year History of Securities at 194-95 (cited in note 99); Ichiro Kawai Dodge Line-Hikishimi de Kabushiki Fukyo (The Dodge Line-Stock Market is in Recession Because of the Strained Economy), in Arisawa, ed, $A$ Hundred-Year History of Securities at 217 (cited in note 99).

200. Takao Nakamura, Gareki no Nakakara-Juten Sangyo ni Shikin Tonyu (Reorganizing from the Rubble-Investing in the Industrial Sector), in Arisawa, ed, A Hundred-Year History of Securities at 184 (cited in note 99); Kaichi Shimura, Fukko Kinyu Kinko no Katsudo-Kikan Sangyo e Yushi Syuchu (Activities of Reconstruction Finance Corporation-Concentrating Loans to Core Industries), in id at 200-03. 
Why did Japan leave the statutory framework of the SEL in place if it was of so little importance in practice? It should be emphasized that in form the disclosure-based framework of the SEL has always been, and continues to be, followed. The point is that it is not an important step in the offering process. It is common in Japanese law and administration for formal legal requirements to be observed, but for the primary direction and focus of market participants to be the applicable administrative requirements or guidelines that are overseen and administered by the government bureaucracies. Indeed, since the TSE's criteria for its merit review system are written and publicly available, this system is easier to identify, describe, and evaluate than administrative rules or guidelines in many other areas, where less information is publicly available.

By its very nature, however, the TSE's merit review system is more subjective and less transparent than a system that allows issuers to access the public markets under a disclosure-based system. It is certainly less transparent than the SEC's administration of the Securities Act, especially given the SEC's detailed public rules, the successive public drafts of registration statements, which permit an evaluation of changes in disclosure following filing with the SEC, and other publicly available documents. Under the Japanese system, what causes a company to be of sufficiently "good" quality to merit a TSE listing is inherently subjective, at least to some degree. When the information on which the merit review is based, the review process itself, and the reasons for which an issuer is not approved (and even the fact that a particular issuer has not been approved) all are not public-as is the case with the TSE's merit review-the system is demonstrably nontransparent. It is thus difficult, if not impossible, to evaluate whether comparably situated participants are being treated comparably. Moreover, all potential participants must either rely on those with access to information about the process ${ }^{201}$ or make judgments based on less-than-complete information.

In addition to the questions raised by a description of the Japanese system for regulating securities offerings as it has developed to date, there are questions about its future development. In particular, there appears to be a trend towards the view that under the impetus of deregulation of the financial markets, it will be increasingly difficult for the Japanese authorities to continue to allow the TSE to impose its judgment as to the quality of a Japanese company, and thereby deny it access to the capital markets. ${ }^{202}$ As a

201. In the case of the TSE merit review process, these are the Japanese licensed securities dealers that are TSE members and are members of the relatively small group of dealers that act as lead underwriters.

202. The commentary on this subject has to date focused more directly on the substantive regulation of the Japanese domestic market for debt securities, which permits only companies that exceed certain quality standards to issue debt in the domestic public markets. The Securities Council established to advise the MOF as to regulatory changes in the securities markets has proposed that these restrictions be loosened and that the markets move to a more disclosure-oriented system. Shoken Torihiki Shingikai Hokoku-Shoken Torihiki ni kakawaru kihonteki Seido no Arikata ni tsuite (The Report 
result, it is suggested that regulation of offerings must inevitably move towards a disclosure-based system.

On the other hand, the recent experiences in the Japanese OTC market, where certain OTC-quoted companies have launched IPOs only to go bankrupt shortly afterwards, ${ }^{203}$ could foreshadow possible difficulties for the Japanese market for public offerings if the reliance on merit review is decreased. The OTC market currently has a lower standard of merit review and no effective outside discipline forcing adequate disclosure, since disclosure standards are not enforced by either the MOF or private litigants under the SEL. A further movement towards market liberalization that is not accompanied by increased attention to disclosure by regulators and market participants and more rigorous enforcement of disclosure standards would then lead to offerings in which the risk from imprecise or misleading disclosure would be borne by the investor since as a practical matter no other participants, including the issuers and underwriters, will be required to take responsibility. To avoid this result, perhaps the regulation of the Japanese offering market will require not only that the disclosure-based system of the SEL be retained, but that its provisions be enforced.

of the Securities Council-Proposals for the Operations of the Securities Exchanges) 13-16, 27-43 (1991). The trend towards deregulation can also be expected to reach the equity markets.

203. See note 151 . 


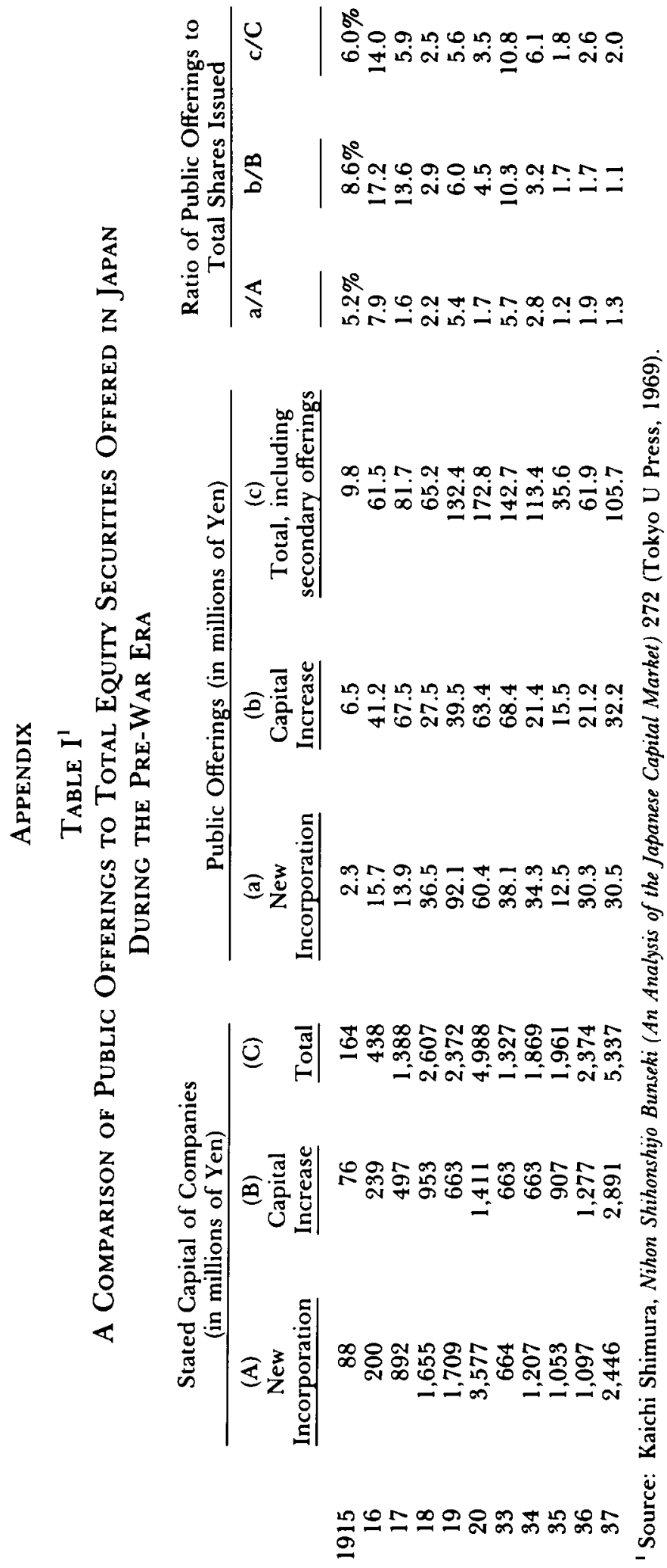




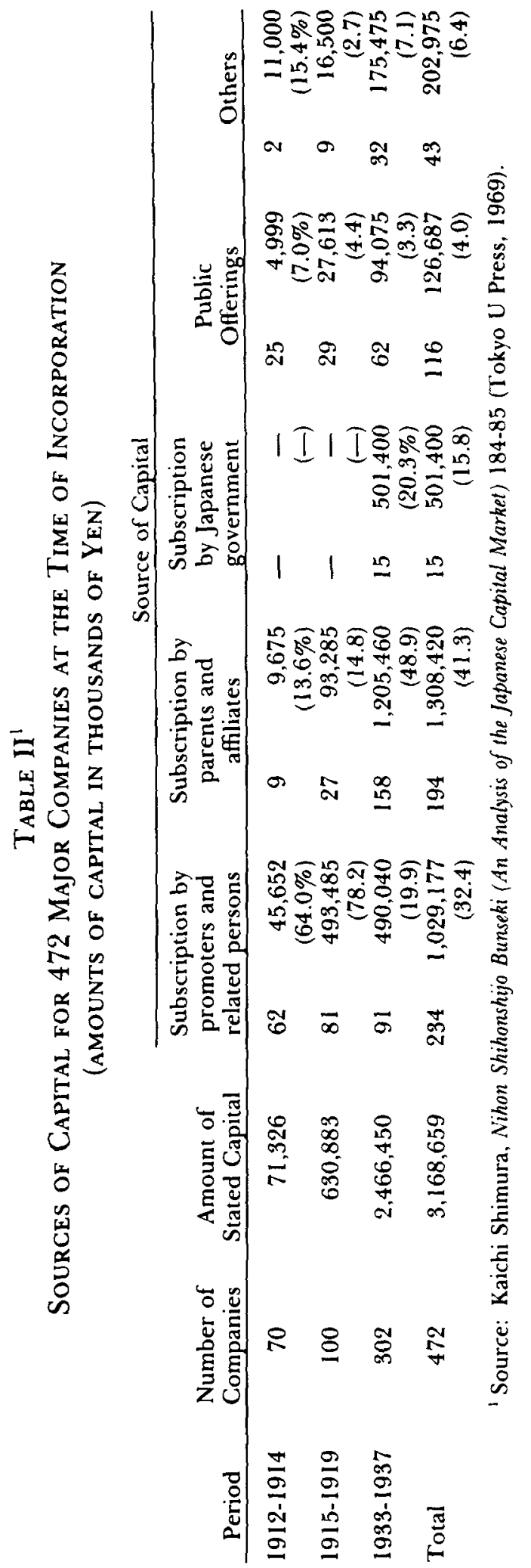




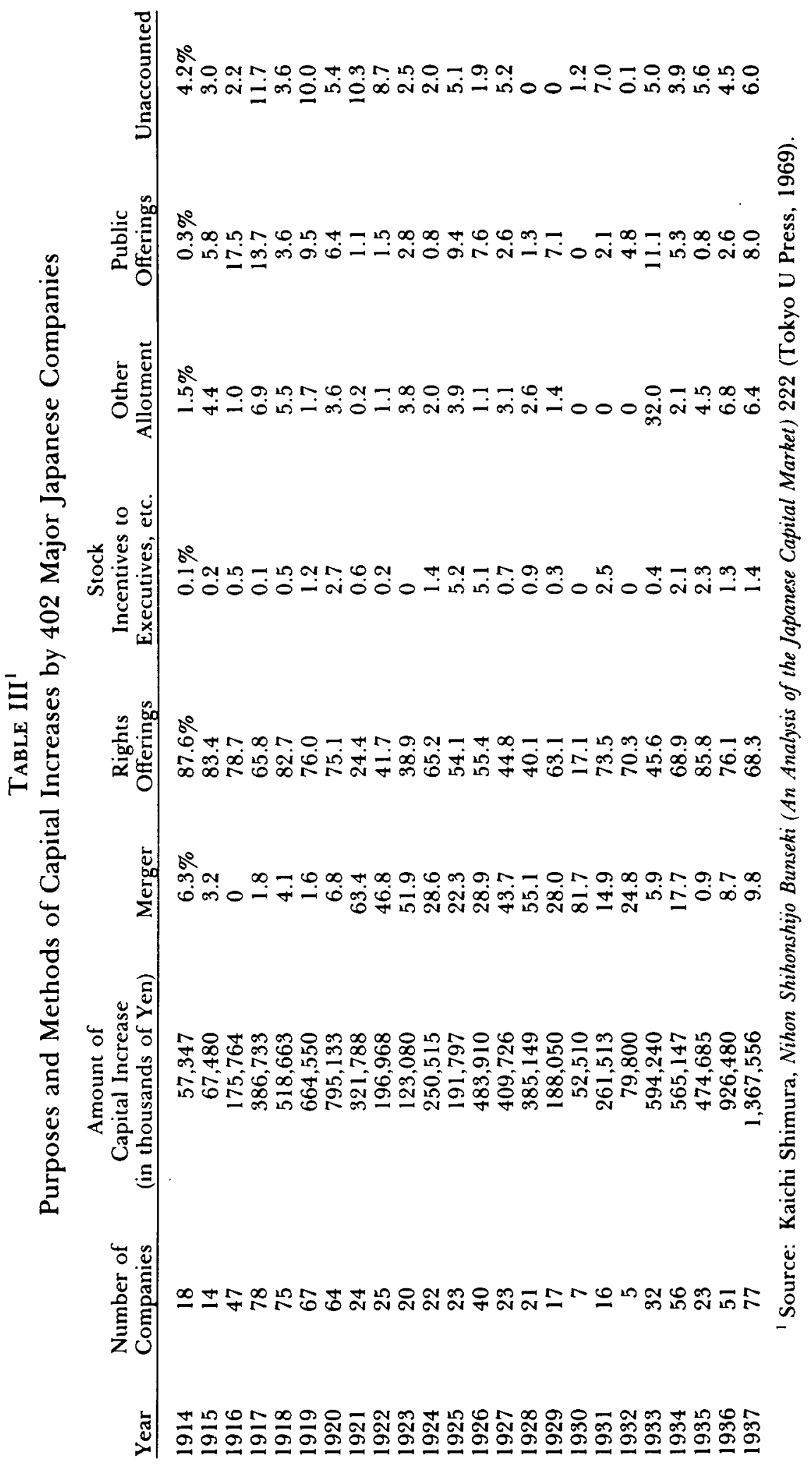


TABLE IV

Transactions on Tokyo Stock Exchange

Year

$\begin{array}{lr}1894 & 1,839,918 \\ 1895 & 2,817,766 \\ 1896 & 3,803,146 \\ 1897 & 3,526,321 \\ 1898 & 3,817,792 \\ 1899 & 5,400,770 \\ 1900 & 3,680,595 \\ 1901 & 2,550,285 \\ 1902 & 2,941,790 \\ 1903 & 1,934,220 \\ 1904 & 2,994,690 \\ 1905 & 6,169,510 \\ 1906 & 12,065,480 \\ 1907 & 12,588,450 \\ 1908 & 9,490,100 \\ 1909 & 11,799,640 \\ 1910 & 11,029,380 \\ 1911 & 10,430,480 \\ 1912 & 12,476,280\end{array}$
Volume of Deliveries

157,689

194,678

373,092

305,918

295,636

507,960

364,105

217,605

334,580

206,660

274,990

520,820

$1,107,530$

$1,394,930$

672,470

952,230

$1,068,300$

973,200

$1,174,950$
No. of Issues

50
57
94
57
44
59
53
42
49
52
52
52
52
52
52
52
52
52
52

${ }^{1}$ Source: T.F.M. Adams, Japanese Securities Markets: A Historical Survey 27 (1953). 